\title{
A emergência e evanescência da nova classe média brasileira
}

\section{The emergence and evanescence of Brazil's new middle class}

\section{Moisés Kopper ${ }^{*}$}

* Max-Planck-Institut für Gesellschaftsforschung - Köln, Deutschland Em pós-doutoramento (bolsista Capes/Humboldt) moiseskopper@gmail.com

Arlei Sander Damo**

** Universidade Federal do Rio Grande do Sul - Porto Alegre, RS, Brasil arleidamo@uol.com.br 


\title{
Resumo
}

Entre 2001 e 2013, o Brasil cresceu e redistribuiu renda. Fruto da estabilidade inflacionária, do aumento do salário mínimo, da expansão do crédito e das políticas sociais, esse período foi marcado pela mobilidade ascendente de milhões de brasileiros. Economistas, jornalistas, políticos e marqueteiros viram na ascensão econômica dessa população a emergência de uma "nova classe média", definida na releitura de estatísticas nacionais e tornada alvo de intervenções governamentais e de mercado. A partir de uma etnografia documental e de entrevistas com experts, este artigo propõe uma arqueologia dessa categoria, problematizando os caminhos taxonômicos de sua emergência e evanescência. Argumentamos que a "nova classe média" deve ser pensada como uma assemblage científica, política e econômica, agenciada, respectivamente, através de alinhamentos estatísticos, governamentais e mercadológicos. Essas escalas difusas de conhecimento e poder cristalizaram frentes discursivas que tornaram a mobilidade econômica inteligível, em um país tradicionalmente conhecido pela estagnação e desigualdade.

Palavras-chave: mobilidade; nova classe média; assemblage; alinhamento.

\begin{abstract}
Between 2001 and 2013, Brazil's economy grew with income redistribution. A result of inflationary stability, minimum wage increase, credit expansion and the widening of social policies, this period was characterized by the upward mobility of dozens of millions of Brazilians. Economists, journalists, politicians and marketers heralded the end of endemic poverty and the incorporation of this population into a newly defined "middle class". Drawing from a documental ethnography, and from interviews with experts, this article pursuits the archeology of this category, problematizing the taxonomic ways of its emergence and evanescence. We argue that the "new middle class" must be understood as a scientific, political, and economic assemblage - one that is performed through statistic, governmental, and marketing alignments. Such diffuse scales of knowledge and power crystallized discursive fronts that rendered economic mobility legible in a country traditionally known for its stagnation and inequality.
\end{abstract}

Keywords: mobility; new middle class; assemblage; alignment. 
A nova classe média nos descaracterizou [...]

Nós não éramos assim.

Nós nunca fomos assim.

[...] acabou [...] o que tínhamos de mais nosso, que era a pirâmide social.

Uma coisa antiga, sólida, estruturada...

Luís Fernando Verissimo, Buuu (2011)

\section{Introdução: uma categoria que desestabilizou ${ }^{1}$}

Em 2012, o indicador clássico de mensuração da desigualdade de renda, o Coeficiente de Gini, ${ }^{2}$ caiu para seu menor patamar desde 1960 (Paes de Barros; Foguel; Ulyssea, 2007). Após mais de uma década de políticas econômicas e sociais - como a estabilidade inflacionária, o aumento do salário mínimo, a expansão do crédito e os programas de transferência de renda -, o Brasil parecia ter finalmente encetado a marcha em direção ao crescimento, ao desenvolvimento e à modernização. Pessoas até então à margem de políticas públicas tiveram uma oportunidade de reimaginar seus futuros como beneficiários de intervenções econômicas e sociais.

Por décadas, a pirâmide social foi a representação hegemônica das segmentações de classe e das altas desigualdades de renda do Brasil. Por volta de 2012, o Coeficiente de Gini e outros indicativos estatísticos apontavam para o declínio da desigualdade, com a migração ascendente da base da pirâmide, que assim parecia não fazer mais sentido. Ou melhor, ela havia entrado em ebulição.

Mudanças na composição da sociedade brasileira desestabilizaram crenças arraigadas sobre a desigualdade, a pobreza e a mobilidade. Novos espaços políticos, econômicos e subjetivos de intervenção sobre as populações que se articularam no lastro dessas transformações foram abertos. Intelectuais com destacada inserção pública passaram a competir pelo enquadramento dessa

1 Este artigo é resultado de pesquisa de doutorado e alguns dos argumentos aqui apresentados são inspirados e/ou desenvolvidos mais pormenorizadamente na tese Arquiteturas da esperança: uma etnografia da mobilidade econômica no Brasil contemporâneo (Kopper, 2016).

2 O Coeficiente de Gini foi criado em 1912 pelo estatístico italiano Corrado Gini para medir o grau de desigualdade social. Nele, os países são distribuídos ao longo de uma escala que varia de zero (onde todos detêm a mesma renda per capita) a um (onde um indivíduo, ou uma pequena parcela da população, detém toda a renda e os demais nada têm). 
população emergente. Era possível falar no surgimento de uma "nova classe média"? Que população heterogênea era essa?

Disputas fervorosas em torno do legado político, econômico e subjetivo dessa mobilidade foram travadas, dali por diante, entre economistas, sociólogos, políticos, jornalistas e marqueteiros para reposicionar o país e as teorizações a respeito de sua estratificação. Desconsertados pela mobilidade de milhões de brasileiros, esses setores da intelligentsia nacional suscitaram uma gramática moral predicada nas fronteiras entre cidadania e consumo para tornar inteligíveis as transformações econômicas e pensar o "novo" Brasil e seus dilemas.

Através de uma incursão etnográfica pela vida pública de alguns personagens da mobilidade, este artigo mapeia as tensões taxonômicas por trás desse debate, e os caminhos pelos quais projetos políticos, científicos e econômicos foram colocados em prática para reafirmar o lugar do país no radar global do desenvolvimento social e econômico, para reforçar tecnologias de governo dos pobres, e para ratificar práticas científicas de mensuração dos números públicos (Neiburg, 2007). Nas próximas páginas, analisamos os desdobramentos da mobilidade econômica no Brasil recente - período que situamos entre $2001 \mathrm{e}$ 2013, apontado pelas estatísticas como sendo o de maior crescimento econômico com redistribuição de renda nas últimas décadas.

Instrumentada em palavras, imagens e práticas, a mobilidade foi agenciada, ${ }^{3}$ concretamente, por meio de assemblages (Collier; Ong, 2005). Referimo-nos a composições - por definição móveis, fugazes e efêmeras - em que se alinharam discursos científicos, políticos, econômicos, morais e subjetivos, para performar uma "nova classe média". Procuramos mapear, portanto, de um ponto de vista antropológico, a arqueologia taxonômica dessa categoria que promoveu convergências e fricções (Tsing, 2005) em diferentes escalas do espectro político e intelectual, problematizando os caminhos de sua emergência e evanescência. Nessa abordagem, mostraremos como a linguagem da "nova classe média" articulou, simultaneamente, diferentes acepções da mobilidade econômica, refletindo-se ainda como um índice de desigualdade social e de distribuição de renda.

3 Baseamo-nos, aqui, no conceito de agenciamento (Callon, 2013, p. 328) e sua capacidade de "souligner la diversité des configurations [...] en même temps que leur unité". Ao assinalar a variedade de configurações possíveis, apontamos também para os efeitos concretos produzidos por um desses alinhamentos - a tese da "nova classe média" - que, ao se tornar hegemônico da interpretação da mobilidade na década de 2000, silenciou outras categorias. 
Aqui, estamos particularmente interessados nos procedimentos de experimentação empregados na constituição dessa assemblage para o desenho de políticas públicas e aberturas de mercado. Muniesa e Callon (2007, p. 163) argumentaram que "to experiment is to attempt to solve a problem by organizing trials that lead to outcomes that are assessed and taken as starting points for further actions". Experimentos performam, por conseguinte, os objetos econômicos que pretendem descrever; seu valor está nos efeitos que são capazes de provocar. Como tecnologias que conduzem à ação, experimentos carregam, por definição, uma concertação temporal da realidade em que expectativas ficcionais (Beckert, 2013) conjecturam uma teleologia do presente, informando o trabalho das peças que compõem a assemblage da mobilidade.

Para destrinchar essa assemblage da mobilidade econômica da década de 2000, faremos uso metodológico do que chamamos aqui de alinhamentos: formações experimentais e fugazes que revelam polarizações e "frentes discursivas" ${ }^{4}$ específicas no interior dessa composição. Como noções estenográficas, os alinhamentos prestam-se a identificar delineamentos ideológicos particulares que se materializam na formação de alianças políticas, científicas e econômicas, e se realizam em espaços privilegiados para a concretização dos embates taxonômicos.

$\mathrm{O}$ artigo mostra, na primeira parte, como alinhamentos estatísticos produziram um entendimento econômico da "nova classe média" que se cristalizou em determinados centros universitários, criou raízes no governo federal, e penetrou no principal instituto nacional de pesquisa aplicada às políticas públicas, o Ipea. Tratamos do trabalho seminal do economista Marcelo Neri - que, em 2008, cunhou a expressão "nova classe média" (Neri, 2008) -, situando-o em relação às constelações mais amplas de poder e saber que permearam a emergência dessa categoria. Neri é parte de uma autoproclamada constelação de economistas "sociais" que, crescentemente, passou a ocupar posições estratégicas na elaboração, avaliação e prognóstico de políticas públicas de caráter social. Mostramos ainda como essa linguagem tecnocrática penetrou certas esferas de planejamento do governo federal, adquirindo tração na formulação

4 Essa noção inspira-se na ideia foucaultiana de "formas discursivas" (Foucault, 1995), enfatizando a dimensão performática de certas modalidades de discurso que operam como feixes de força e agem como um dispositivo visando antecipar outras ações. Essas frentes criam um cenário do possível, do legítimo e até mesmo do desejável. 
de um novo modelo de estratificação da sociedade brasileira, e influenciou a proposição e execução de políticas públicas. Na segunda metade exploramos os efeitos produzidos por essa assemblage taxonômica da mobilidade. Analisamos como outro alinhamento, em grande medida induzido pelo primeiro, embora de natureza essencialmente difusa, concentrou as diversas escalas de contestação da tese da "nova classe média", sendo enunciada por filósofos, sociólogos, e, em menor medida, economistas. Identificamos também os desdobramos de outro alinhamento, em torno do qual gravitaram marqueteiros e publicitários empenhados em converter a "tese da nova classe média" em artefato de um mercado específico: aquele da "base da pirâmide". Exploramos as apropriações criativas dessa linguagem na criação de agências de pesquisa de mercado e, sobretudo, de profissionais especializados no prognóstico e comportamento dessa suposta nova classe de sujeitos. Na conclusão, argumentamos que, apesar da efemeridade da "nova classe média" como linguagem política e moral de um "Novo Brasil", a mobilidade econômica por ela descrita trouxe efeitos de longo prazo que merecem ser estudados, e que deixam em aberto o futuro dessa população e o da estratificação brasileira.

\section{A emergência e hegemonia da "nova classe média"}

\section{Os antecedentes do debate}

Por longas décadas, a desigualdade social brasileira, de amplas proporções, afirmada na metáfora da pirâmide por intelectuais, literários e compositores, ocupou cientistas sociais de todos os credos e tornou-se uma espécie de ícone internacionalmente conhecido da identidade nacional (Oliven, 1989, 2002; Ortiz, 1985; Souza, 2000). Dizia-se que a sociedade brasileira, apesar de riquezas naturais e econômicas abundantes, tinha sérios problemas na distribuição desses bens. Na busca por uma explicação para as origens da má distribuição da riqueza, culpavam-se ora as origens luso-imperiais (Freyre, 2006; Holanda, 2006), ora o conservadorismo das elites nacionais (Faoro, 2008; Prado Jr., 1999, 2012a, 2012b; Silveira; Abreu; Losso, 2010), ora a fraqueza e inanição institucional (Carraro; Fonseca, 2003; Furtado, 2007). Um país rico em recursos, porém com muitas pessoas pobres, foi o jargão que se cristalizou dessas interpretações. 
Nos anos 1970, o economista Delfim Netto, ministro da Fazenda em vários governos militares, transformou a desigualdade social numa filosofia de governo, sugerindo que era preciso "fazer o bolo crescer para depois dividi-lo". Waldir Quadros (1991) cristalizou a expansão econômica dessa década na formação de uma "nova classe média" urbana - composta de funcionários públicos, gerentes, profissionais liberais assalariados, professores, empregados do comércio e de escritório beneficiados pela industrialização primária, de capital e de bens de consumo duráveis (Quadros, 1985, 1991). Alinhando o desenvolvimentismo ao capitalismo mundial, a pirâmide social brasileira figurava como a representação gráfica mais contundente e bem-acabada do Brasil, um dos países mais desiguais do mundo. Ela permitia demonstrar como a pobreza estava situada em sua ampla base, convertendo-se progressivamente em riqueza à medida que se atingia o seu topo - porém, com um número cada vez menor de partícipes desse "bolo".

Em 1988 a redemocratização trouxe a promulgação de uma nova constituição. Ela consagrou o ideário da universalização das políticas sociais no país, em um cenário pouco favorável à sua concretização, a chamada "década perdida": instabilidade econômica; crise nas finanças públicas nacionais; Consenso de Washington; dependência financeira com o Fundo Monetário Internacional (FMI) e o Banco Mundial; expansão do neoliberalismo em nível global. Nesse contexto, cientistas políticos sugeriram que a intervenção sobre certos setores da economia de um Estado clientelista, paternalista e com precária infraestrutura produzira um sistema público de seguridade social com direitos universais, mas acesso excludente, limitado a trabalhadores formais, o que desfavorecia os pobres, limitava sua mobilidade, e ampliava ainda mais a desigualdade de renda (Franzoni; Sánchez-Ancochea, 2013).

Em 2000, após uma década de discussões públicas, políticas e legais que converteram a pobreza em problema de governo (Sprandel, 2004) o economista Ricardo Paes de Barros - tido como um dos maiores planejadores de políticas públicas no Brasil -, coordenou um estudo presidido pelo Instituto de Pesquisas Econômicas Aplicadas (Ipea) em que criticou o caráter persistente e naturalizado da desigualdade brasileira (Paes de Barros; Henriques; Mendonça, 2000). O pressuposto desse estudo era que a origem da pobreza brasileira não estava na escassez de recursos, absoluta ou relativa, mas na distribuição desigual da renda estável. A redução nos níveis de pobreza dependia mais de diminuições 
na taxa de desigualdade que de incrementos no crescimento econômico, mensurado pela evolução do PIB. Após os fracassos das políticas de combate à pobreza dos anos 1990, os autores sugeriram que "a sociedade brasileira ousaria, com responsabilidade, ao definir a busca de maior equidade social como elemento central de uma estratégia de combate à pobreza" (Paes de Barros; Henriques; Mendonça, 2000, p. 139).

Imagens como a da pirâmide e a do bolo, um dia já empregadas como poderosas metáforas para representar a sociedade e que circularam como verdades livremente aceitas sobre a sua estratificação, passaram a ser criticamente invocadas a partir da década de 2000 para falar da emergência de um "Novo Brasil". Como representações holográficas da estratificação, elas recriaram as mudanças na distribuição de renda em esquemas visuais que, ademais, aventaram prognósticos de crescimento da classe média que passaram a ser retratados na figura do losango social (Figura 1).

\section{Aumento da renda transforma pirâmide social em losango}

\section{Classe $C$ já é maioria}

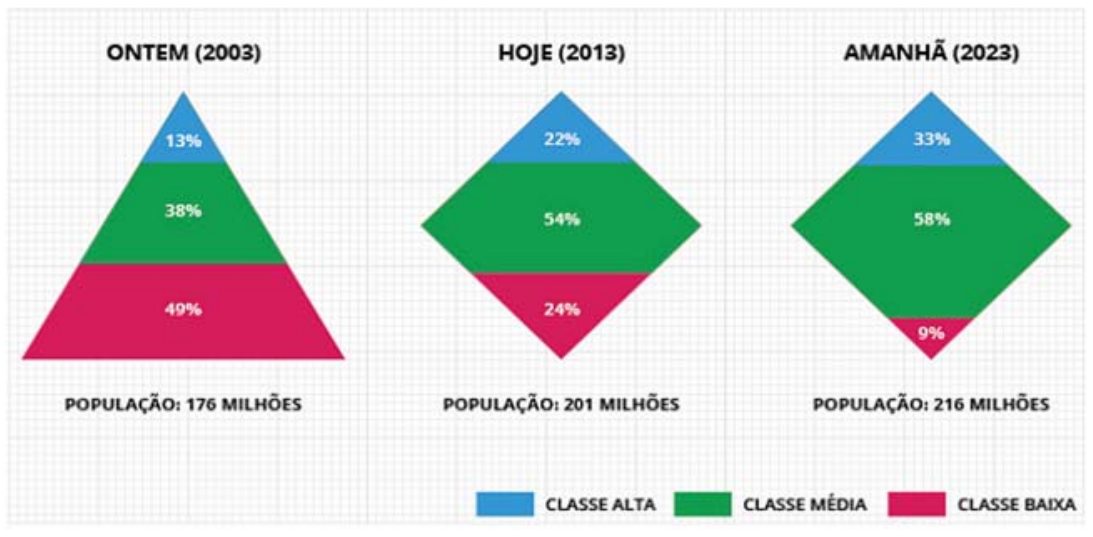

Fonte:Serasa Experian /Data Popular

Figura 1. A pirâmide e o losango. 
Em 2010, o comunicado do então presidente do Ipea, Marcio Pochmann, mensurou os avanços alcançados pelo país no enfrentamento à pobreza e desigualdade desde 2001. Refletindo as conclusões de um estudo de amplo impacto organizado por Paes de Barros, Foguel e Ulyssea (2007) sobre uma incipiente redução das desigualdades com redistribuição de renda, ele enfatizou que, na década de 2000, a "melhoria social" resultara da estabilidade monetária, da expansão econômica com aumento do emprego formal e, sobretudo, da ampliação de políticas públicas. Estas incluíam a elevação real do salário mínimo, a ampliação do crédito popular através do mercado interno, e a reformulação e expansão dos programas de transferências condicionadas de renda.

Uma dessas políticas, o salário mínimo, foi criado por Getúlio Vargas nos anos 1930 e constitui, atualmente, a remuneração básica de 46,7 milhões de brasileiros. Seu reajuste anual, promovido pelo governo em relação à taxa de inflação, objetiva manter ou expandir a capacidade de compra da população assalariada. Com a estabilidade econômica e o controle da inflação propiciados pelo Plano Real de 1994, os ganhos no poder aquisitivo do salário mínimo se expandiram rapidamente: entre 1994 e 1999, o ganho acumulado foi de $28,3 \%$; durante os anos 2000 , a valorização foi de $76 \%$ - a maior desde a redemocratização. Segundo relatório da Organização Internacional do Trabalho (OIT), entre 2000 e 2011 o Brasil passou da $14^{\mathrm{a}}$ para a $4^{\mathrm{a}}$ posição no ranking dos países que mais valorizaram o salário mínimo: o valor passou de $\mathrm{R} \$ 151,00$ (US\$ 62,90) para R\$ 545,00 (US\$ 227,00). A política de valorização do salário mínimo afetou sobretudo a população economicamente ativa brasileira - o que, aliado ao bônus demográfico, foi responsável pela queda na taxa de desemprego observada ao longo da década, que fechou 2002 em 12,6\% e 2014 em $4,8 \%$.

O aumento real do salário mínimo e a consequente queda do desemprego formal coincidiram com políticas de expansão do crédito. Como notou Müller (2013, p. 2), a disseminação de serviços bancários e de instrumentos de crédito a taxas de juros menores - subsidiadas pelo Banco Nacional de Desenvolvimento Econômico e Social (BNDES) - e com maior facilidade de acesso aos pobres já estava prevista no Plano Plurianual de 2004-2007 como forma de "alavancar o desenvolvimento econômico". Somado a isso, o governo federal apostou no desenvolvimento do mercado de consumo interno como estratégia de superação da crise de 2008 , encabeçando subsídios fiscais a setores da 
indústria - como o Imposto sobre Produtos Industrializados (IPI), que afetou eletrodomésticos da linha branca e veículos automotores.

Finalmente, as políticas de redistribuição foram impactadas pelos programas de transferência condicionada de renda, iniciados em nível municipal em 1995 com o Programa Bolsa Escola. Baseado na iniciativa mexicana Oportunidades, em 2003, o governo Lula promoveu sua unificação com a criação do Programa Bolsa Família. Visando à "inclusão social" e à reparação histórica da pobreza estrutural - que passava a ser entendida em sua pluralidade de causas, efeitos e modos de intervenção (Silva e Silva, 2007) - o programa beneficiava 14 milhões de famílias em 2015 com um investimento anual de 0,5\% do PIB. Os efeitos da transferência de dinheiro - condicionada à vacinação e à matrícula escolar das crianças - deslocaram as imagens arraigadas sobre a pobreza que projetavam os beneficiários como maus administrares do dinheiro, ociosos e oportunistas. Como mostraram etnografias recentes sobre o tema, o Bolsa Família inauguraria a ideia de que as políticas sociais brasileiras devem empoderar seus beneficiários, garantindo-lhes, por meio da transferência direta de ativos preferencialmente às mulheres, a autonomia para perseguirem seus próprios projetos de vida (Eger; Damo, 2014).

Como as conclusões do Ipea apontaram, o Brasil da década de 2000 finalmente deixava os piores postos nos rankings de estatísticas sociais globais (Medeiros, 2003; Osorio et al., 2011; Pochmann, 2008; Rocha, 2000; Soares, 2008). Com a queda nos indicadores de desigualdade, a população já podia desfrutar dos benefícios de uma incipiente redistribuição, acompanhada de um crescimento econômico acumulado de $40 \%$ entre 2004 e 2013, e de $58 \%$ de aumento da renda média das famílias no mesmo período, apesar da recessão internacional. A pirâmide cedia lugar, doravante, à imagem do "losango" ou "diamante" social: a renda já não se concentrava exclusivamente no topo da estratificação, tendo se deslocado para suas camadas intermediárias - e era desejável, segundo uma miríade de agências internacionais, que assim o fosse. Perdíamos, pois, a possibilidade de descrever nossa sociedade por meio de uma de suas figuras mais persuasivas, a da pirâmide social - nas palavras de Verissimo (2011): "Essa coisa antiga, sólida, estruturada..." 


\section{A "classe média" dos economistas e a performance dos números públicos}

Em 2008, Marcelo Neri lançou em livro uma pesquisa de grande vulto à frente do Centro de Políticas Sociais (CPS) da Fundação Getúlio Vargas (FGV), chamado A nova classe média: o lado brilhante dos pobres (Neri, 2008). A "classe média", segundo o economista, passou a englobar famílias com renda domiciliar entre R\$ 1.126,00 e R\$ 4.854,00 (valores de $2009^{5}$ ) - cerca de US\$ 470,00 e US\$ $2.022,00$-, o que perfazia mais de $50 \%$ da população e a tornava uma espécie de retrato da sociedade brasileira.

Para forjar a "tese da nova classe média" (Salata, 2013, 2014) Marcelo Neri apropriou-se de debates internacionais - realizados no Banco Mundial, por exemplo (Ravallion, 2009) - que discutiam a pertinência de novas mensurações estatísticas para a estratificação em países em desenvolvimento. ${ }^{6}$ Essa seria uma tendência já observada em outros países da América Latina, onde a mobilidade econômica tornara-se a pauta política, intelectual e midiática do dia (Ferreira et al., 2013). No Brasil, os antecedentes desse debate remontam ao trabalho seminal de Carlos Langoni (1973), ao uso pioneiro das estatísticas (Kopper, 2015, 2016, cap. 1) e das controvérsias associadas ao uso desse instrumento como ferramenta de governo.

Recorrendo a sentenças e situações ordinárias, o economista discutiu novos paradigmas de mensuração econômica e social da queda da desigualdade brasileira. Ao longo do livro, ele insistiu em um argumento de longo alcance que encontraria ressonância no interior da maquinaria estatal: o da existência de dois Brasis retratados por meio de uma tensão entre abordagens macro e microeconômicas. Como afirmaria em outra ocasião, "tem um Brasil das contas nacionais, que governa a maioria das análises econômicas, e há um Brasil que visita as casas das pessoas, que é o das pesquisas domiciliares. Um está descolado do outro" (Renda..., 2014). Neri sugeriu haver um descompasso

5 Neste artigo, adotamos cotações de dólar de 2009 para preservar a paridade do poder de compra em real da época.

6 Ravallion (2009), por exemplo, argumenta que crescimento econômico tende a produzir classes médias em expansão. Para ele, as classes médias em países em desenvolvimento (os Brics: Brasil, Rússia, Índia, China e África do Sul) devem ter como limite inferior US\$ 2,00 e superior US\$ 13,00 (linha de pobreza americana). Nesse critério, 1,2 bilhão de pessoas juntaram-se de 1990 a 2005 às novas classes médias nesses países. 
entre o resultado de indicadores convencionais de avanço da economia - como a taxa de crescimento do Produto Interno Bruto (PIB) - e a progressiva diminuição da desigualdade de renda brasileira, mensurada por meio do poder de compra das famílias captado pela Pesquisa Nacional por Amostra de Domicílios (PNAD):? entre 2003 e 2009, o PIB crescera a uma "modesta" taxa média anual de $2,88 \%$, enquanto a renda da PNAD crescera a taxas entre $4,7 \%$ e $7 \%$ - quase o dobro, portanto.

Ao confrontar indicadores como PIB e PNAD, Neri sugeriu um novo modelo de mensuração do crescimento brasileiro que não se amparava no produto interno como indicador de bem-estar da nação, mas no poder de compra (a renda) de seus cidadãos. Neri abria as portas para uma imaginação econômica baseada menos na produtividade nacional e mais nos efeitos redistributivos de políticas públicas. Como veremos, essa abordagem dos números encaixar-se-ia em uma perspectiva desenvolvimentista de Estado em construção e demarcaria uma nova etapa nas relações entre economistas e planejamento de políticas sociais.

Na busca por um entendimento mais alargado das estatísticas - e de respostas para questões como "e aí, melhorou ou piorou a vida dos brasileiros?" (Neri, 2011, p. 6) -, Neri fez uso do conceito de "classes econômicas", ${ }^{8}$ valendo-se da segmentação em cinco estratos proposta pelo "Critério de Classificação Econômica Brasil” (CCEB). Conhecido como Critério Brasil, este índice é uma estimativa padronizada da capacidade de consumo dos domicílios brasileiros e foi desenvolvido pela Associação Brasileira de Empresas de Pesquisa (Abep) com

7 A PNAD traz informações anuais sobre características demográficas e socioeconômicas da população (sexo, idade, educação, trabalho e rendimento) e características dos domicílios, além de informações sobre migração, fecundidade, nupcialidade e é considerada o instrumento brasileiro mais completo de produção de dados - uma espécie de retrato da sociedade nacional, a partir da qual "debatemos nossas conquistas e percalços" (Neri, 2008, p. 6). Realizado desde 1967, o survey integra o Programa Nacional de Pesquisas Contínuas por Amostra de Domicílios, do IBGE, e foi inicialmente concebido com o objetivo de suprir a falta de informações básicas sobre a população durante o período intercensitário, concentrando-se em temas insuficientemente investigados ou não contemplados nos Censos Demográficos (Instituto Brasileiro de Geografia e Estatística, 1991, p. 7).

8 O termo é proposital para diferenciar seu uso do de sociólogos. Ainda no primeiro capítulo lemos: "Os sociólogos podem relaxar, pois não estamos falando de classes sociais (operariado, burguesia, capitalistas, etc.), mas de estratos econômicos. Leia-se, dinheiro no bolso, que seria, segundo os economistas, a parte mais sensível da anatomia humana [sic]" (Neri, 2011, p. 17). 
base na Pesquisa de Orçamentos Familiares (POF). ${ }^{9}$ A metodologia está atrelada à posse de determinados bens ${ }^{10}$ que, compondo uma hierarquia de pontos, informam as fronteiras de classe econômica.

Neri apropriou-se do Critério Brasil não para definir as fronteiras de classe, mas para avaliar o potencial de consumo das famílias divididas em classes de renda através de outra noção estatística: a mediana - uma linha imaginária que divide a população em duas metades iguais. O procedimento do economista consistiu em calcular a faixa de renda que caracteriza o intervalo composto pelos $40 \%$ da população acima da mediana e abaixo dos $10 \%$ mais ricos em 2004, inflacionando-a para preços de 2008. Neri dispôs as classes econômicas nesse recorte arbitrário inicial que pressupõe uma classe intermediária composta de $40 \%$ da população em 2004, equacionando-as segundo cálculos de renda domiciliar per capita advinda sobretudo do trabalho. Com isso, ele mostrou os movimentos para cima e para baixo desses segmentos no tempo. Na Tabela 1 e na Figura 2 a seguir vemos como a classe $C$ manteve-se relativamente estável entre 1995 e 2003 - em torno de 32\% da população -, passando a crescer no ano seguinte e atingindo 50,5\% da população em 2009 (35\% de aumento). Em números absolutos, entre 2003 e 2009, as classes E e D tiveram uma diminuição de mais de 20 milhões de pessoas, contrabalançadas pela passagem de mais de 29 milhões para a classe $C$ e 6,5 milhões para as classes A e B (cf. Neri, 2008, p. 12).

9 A Pesquisa de Orçamentos Familiares é executada pelo IBGE e busca obter informações gerais sobre domicílios, famílias e pessoas, hábitos de consumo, despesas e recebimentos das famílias pesquisadas, tendo como unidade de coleta os domicílios. Atualiza a cesta básica de consumo e obtém novas estruturas de ponderação para os índices de preços que compõem o Sistema Nacional de Índices de Preços ao Consumidor do IBGE e de outras instituições.

10 Se por um lado especialistas concordam em que a presença de bens duráveis atrelada ao grau de escolaridade do chefe de família é uma medida menos flutuante que a renda corrente, por outro o Critério Brasil sofre várias críticas quanto à escolha do tipo de bens que entram na classificação. Em janeiro de 2015, por exemplo, numa tentativa de manter o modelo alinhado com a dinâmica da economia brasileira, novos itens passaram a compor a pontuação, tais como o acesso a certos serviços públicos (água encanada e rua pavimentada), microcomputador, lava-louças, micro-ondas, motocicleta e secadora de roupas, ao passo que outras variáveis, como televisão em cores, rádio e videocassete, foram excluídas por serem consideradas defasadas na demarcação da classe. Outros itens, como o número de banheiros, de automóveis e de empregadas domésticas, permaneceram constantes. Com isso, as mudanças históricas na composição da metodologia terminam por inviabilizar comparações longitudinais, quebrando a série histórica de dados. Sem uma metodologia constante, não seria possível avaliar aumentos ou diminuições nas classes brasileiras. 
Tabela 1. Definição das classes econômicas (adaptado de Neri, 2008).

\begin{tabular}{ccc}
\hline \multicolumn{3}{c}{ Renda domiciliar total de todas as fontes } \\
\hline Inferior (em R\$) & Limite superior (em R\$) \\
\hline Classe E & 0 & 705 \\
\hline Classe D & 705 & 1126 \\
\hline Classe C & 1126 & 4854 \\
\hline Classe B & 4854 & 6329 \\
\hline Classe A & 6329 & - \\
\hline
\end{tabular}

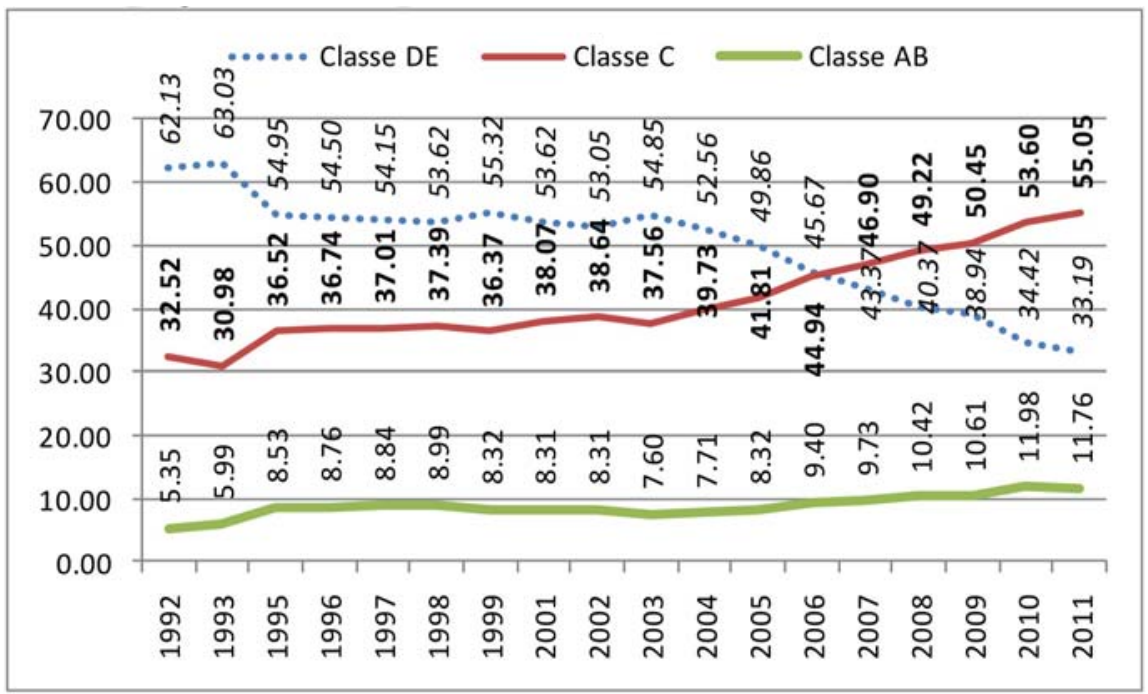

Fonte: CPS/ FGV a partir dos microdados da PNAD e da PME/IBGE

Figura 2. Evolução da participação de grupos de classes econômicas.

Ao situar a faixa C entre os "remediados" e a "elite", Neri (2011, p. 14-15) a definiu como um espelho persuasivo da sociedade brasileira como um todo. Jogando com metáforas, tropos do senso comum e comparações com países de distribuições de renda distintas, ele sugeriu que uma análise apropriada das atitudes e 
valores da "classe C" conduziria a um retrato fidedigno do que o país se tornara nos anos recentes.

Heuristicamente, os limites da classe $\mathrm{C}$ seriam as fronteiras para o lado indiano e para o lado belga da nossa Belíndia." Investigamos as migrações entre estes diferentes Brasis. A classe $C$ aufere em média a renda média da sociedade, ou seja, é classe média no sentido estatístico. A classe $C$ é a imagem mais próxima da média da sociedade brasileira. (Neri, 2008, p. 29).

A fim de decompor as expectativas e "faces" da nova classe média, Neri se apoiou na combinação de diferentes surveys que ressaltam a importância do trabalho como fator decisivo de ascensão social. "A carteira de trabalho é o maior símbolo da ascensão como ato consumado, e o concurso público é seu platônico objeto de desejo" (Neri, 2011, p. 19). Ao criar dois índices - um de potencial de consumo (incluindo bens duráveis, serviços públicos e moradia) e o outro de produção (incluindo potencial de geração de renda familiar e investimentos em capital físico, social e humano) - Neri sugeriu que o aumento da renda do trabalho foi o que mais impulsionou o crescimento da nova classe média. "Nos termos da fábula de La Fontaine", continuou, "o brasileiro está virando menos cigarra e mais formiga" (Neri, 2011, p. 34).

A partir de indicadores como o trabalho, o potencial de consumo e de produção, Neri (2011, p. 18) deslocou a discussão do registro estatístico para o valorativo, embutindo em sua nova classe média "um sentido positivo e prospectivo daquele que realizou - e continua a realizar - o sonho de subir na vida". Uma vez definidas as faixas arbitrárias de renda, sua especificidade consistiu em perguntar-se sobre questões não econômicas e respondê-las por meio de quantificações e decomposições analíticas. "Em nossa visão, baseada em renda sobre nova classe média, aninhamos expectativas subjetivas das pessoas e seus respectivos estoques de ativos físicos, humanos e sociais" (Neri, 2011, p. 19). Nesse processo, Neri procedeu ainda a uma segunda passagem, da classe $C$ à "nova classe média: "classe C soava depreciativo, pior do que classe A ou B, por

11 A noção de "Belíndia" foi popularizada pelo economista Edmar Bacha (1974). Ele argumentava que o regime militar havia criado um país dividido entre os que moravam em condições socioeconômicas similares à Bélgica e aqueles com padrão de vida da Índia. 
exemplo. Nova Classe Média difere em espírito da expressão nouveau riche, que acima de tudo discrimina a origem das pessoas" (Neri, 2011, p. 18). Sua abordagem articulou, então, o instrumental microestatístico das bases de dados a uma imagem sui generis do brasileiro médio em vias de ascensão: "Aonde você vai chegar é mais importante do que de onde você veio ou onde está. Nova classe média não é definida pelo ter, mas pela dialética entre ser e estar olhando para a posse de ativos e para decisões de escolha entre o hoje e o amanhã" (Neri, 2011, p. 18). Nesse movimento conceitual das classes econômicas para as classes sociais, Neri destrinchou as tendências de renda, escolaridade, religião, sexo, etnia, geração, gênero e região que caracterizavam esse novo estrato intermediário (para uma discussão mais detalhada, ver Kopper, 2016).

Os cruzamentos analíticos foram fundamentais, como veremos, para a abertura de novos mercados populares destinados à "base da pirâmide" ao longo dos anos 2000. Eles informariam o design de pesquisas de mercado voltadas a descobrir as necessidades e valores desse novo segmento de pessoas, e sua focalização em subpopulações tidas como representativas da sociedade brasileira como um todo e da "nova classe média" em particular: os negros, as mulheres e os jovens. Alguns desses desdobramentos serão analisados na sequência do artigo.

\section{Da ciência ao governo}

A possibilidade de proclamar o Brasil um país de "classe média" chamou a atenção do governo federal. Este reuniu, ainda em 2011, uma comissão, composta de intelectuais e políticos, para discutir o assunto. Sob os auspícios da Secretaria de Assuntos Estratégicos da Presidência da República (SAE-PR), ${ }^{12}$ foi formulado um novo critério oficial de estratificação da sociedade brasileira no ano seguinte (Tabela 2). Nesse esforço - que buscava mapear e sistematizar

12 Com status de ministério, a secretaria foi criada em 2008, durante o segundo mandato do presidente Luiz Inácio Lula da Silva, e foi inicialmente coordenada por Mangabeira Unger - filósofo da Universidade de Harvard filiado ao partido do então vice-presidente, José de Alencar (PRB). Tendo como missão desenvolver políticas públicas de longo prazo voltadas à prosperidade econômica e social do Brasil, a secretaria se inseria na complexa história do repertório de planos de desenvolvimento que caracterizaram o Estado brasileiro desde a década de 1930 e que tiveram novo enfoque com a criação do Ministério do Planejamento, em 1962, e do Ipea, em 1964. 
conceitos de classe média com vistas à sua aplicação à realidade brasileira - a abordagem de Marcelo Neri foi combinada a um modelo matemático de estimação da vulnerabilidade. A iniciativa desembocou no projeto "Vozes da Classe Média", que perdurou até 2015, procurando decifrar as expectativas e desejos dessa população para aperfeiçoar a formulação de políticas econômicas do Estado. A proposta combinava um governo de proteção social com expansão de mercado, e cristalizava o que Neri (2011, p. 240) havia chamado de "o caminho do meio": "O desafio é combinar as virtudes do Estado com as virtudes dos mercados, sem esquecer de evitar as falhas de cada um dos lados."

Tabela 2. Novo critério de estratificação social da SAE-PR (esquematização: autores)

\begin{tabular}{|c|c|c|c|c|}
\hline & $\begin{array}{l}\text { Faixas de renda per } \\
\text { capita familiar (em } \\
\text { 2012) }\end{array}$ & $\begin{array}{l}\text { Renda familiar média } \\
\text { (para família de } 4 \\
\text { membros) }\end{array}$ & $\begin{array}{c}\text { Vulnera- } \\
\text { bilidade } \\
\text { (probabi- } \\
\text { lidade de } \\
\text { voltar à } \\
\text { pobreza) }\end{array}$ & $\begin{array}{c}\% \text { da } \\
\text { população }\end{array}$ \\
\hline $\begin{array}{l}\text { Extremamente } \\
\text { pobre }\end{array}$ & $\begin{array}{l}\text { Até } \mathrm{R} \$ 81,00 \\
\text { (US\$ } \$ 4,00)\end{array}$ & $\begin{array}{l}\text { Até } \mathrm{R} \$ 324,00 \\
\text { (meio SM) }\end{array}$ & N.A. & $5 \%$ \\
\hline Pobre & $\begin{array}{l}\mathrm{R} \$ 82,00-161,00 \\
\quad(\text { US } \$ 67,00)\end{array}$ & $\begin{array}{c}\mathrm{R} \$ 324,00-644,00 \\
(1 \mathrm{SM})\end{array}$ & N.A. & $10 \%$ \\
\hline Vulnerável & $\begin{array}{l}\mathrm{R} \$ 162,00-291,00 \\
(\mathrm{US} \$ 121,25)\end{array}$ & $\begin{array}{c}\mathrm{R} \$ 644,00-1.164,00 \\
(1,8 \mathrm{SM})\end{array}$ & N.A. & $19 \%$ \\
\hline $\begin{array}{l}\text { (Nova) classe } \\
\text { média }\end{array}$ & $\begin{array}{l}\mathrm{R} \$ 292,00-441,00 \\
\text { (US\$184,00) }\end{array}$ & $\begin{array}{c}\mathrm{R} \$ 1.164,00-1.764,00 \\
(2,8 \mathrm{SM})\end{array}$ & Até um ano & $17 \%$ \\
\hline $\begin{array}{l}\text { (Nova) classe } \\
\text { média média }\end{array}$ & $\begin{array}{c}\mathrm{R} \$ 442,00-641,00 \\
\text { (US\$ 267) }\end{array}$ & $\begin{array}{c}\mathrm{R} \$ 1.764,00-2.564,00 \\
(4,1 \mathrm{SM})\end{array}$ & $\begin{array}{l}\text { De um a } \\
\text { cinco anos }\end{array}$ & $17 \%$ \\
\hline $\begin{array}{l}\text { (Nova) classe } \\
\text { média alta }\end{array}$ & $\begin{array}{c}\mathrm{R} \$ 642,00- \\
1.019,00 \text { (US\$ 425) }\end{array}$ & $\begin{array}{c}\mathrm{R} \$ 2.564,00-4.076,00 \\
(6,5 \mathrm{SM})\end{array}$ & $\begin{array}{c}\text { Mais de } \\
\text { cinco anos }\end{array}$ & $15 \%$ \\
\hline $\begin{array}{l}\text { Baixa classe } \\
\text { alta }\end{array}$ & $\begin{array}{l}\mathrm{R} \$ 1.020,00 \\
-2.480,00 \\
\text { (US\$1.033) }\end{array}$ & $\begin{array}{l}\mathrm{R} \$ 4.076,00- \\
9.920,00 \\
(16 \mathrm{SM})\end{array}$ & N.A. & $13 \%$ \\
\hline Alta classe alta & $\begin{array}{c}\text { Acima de } \\
\mathrm{R} \$ 2.480,00\end{array}$ & Acima de $\mathrm{R} \$ 9.920,00$ & N.A. & $4 \%$ \\
\hline
\end{tabular}

Marcelo Neri foi uma figura-chave para os desígnios do governo federal, num momento em que suas ideias sobre o desenvolvimento de uma nova classe média - para ele resultado da expansão do mercado de consumo interno e do 
aumento no número de empregos formais - adquiriram uma base de justificação estatística. Até então, suas filiações institucionais e intelectuais (lembremos que Neri era graduado pela PUC-RJ e afiliado à FGV) o situavam à direita do espectro político (Loureiro; Lima, 1994), razão pela qual nunca foi considerado pelo governo petista para integrar seu quadro de gestores. No entanto, desde 2004, à medida que seu foco de pesquisa se voltava para políticas públicas, Neri passou a desenvolver estudos estatísticos de desigualdade que foram bem vistos pelo governo petista.

Em outubro de 2008, o então presidente Luiz Inácio Lula da Silva declarou-se otimista quanto aos efeitos da crise estadunidense no Brasil ${ }^{13}$ que naquele momento atingia o seu ápice e arrastava consigo quase todos os países europeus. Bem ao seu estilo, Lula sugeriu que o "tsunami", se chegasse ao Brasil, teria o efeito de uma "marolinha". ${ }^{14} \mathrm{~A}$ fim de minorar seus impactos, o governo concentrou-se no estímulo ao mercado interno: reduções sucessivas de impostos na indústria automobilística e de eletrodomésticos tornaram-se realidade cotidiana, elevando os índices de otimismo da população. Nesse cenário, o livro de Neri garantiu a legitimidade científica de uma conquista simbólica a ser preservada - a "saída" da pobreza de um contingente expressivo de brasileiros e de uma estratégia de recuperação: a ênfase na criação e estímulo de mercados de baixa renda. Sua autoridade advinha não apenas da trajetória por ambientes acadêmicos internacionais, mas sobretudo da proeza de seus argumentos, corroborados por números, em forma de gráficos e tabelas, reproduzidos pela imprensa internacional à medida que a "marolinha" provava-se verdadeira. ${ }^{15}$

13 A crise estadunidense eclodiu com o pedido de falência do quarto maior banco de investimentos americano, Lehman Brothers, e está baseada na falência do modelo de hipotecas subprime, cujos prenúncios se fizeram sentir já em 2006, após rápida valorização do mercado imobiliário. Esses empréstimos eram concedidos a pessoas de baixa renda, com histórico de inadimplência, sem comprovação de rendimentos. Considerados de alto risco, implicaram a elevação da taxa de juros e o não recebimento desses títulos de dívidas pelos compradores, o que gerou uma crise de liquidez.

14 É preciso enfatizar, aqui, a coincidência temporal entre o modelo adotado pelo governo brasileiro para enfrentar a crise internacional e a discussão de Neri sobre a "nova classe média". Ao escolher incentivar o consumo interno de massa, o governo rejeitava uma perspectiva macroeconômica e liberal da contenção de gastos públicos.

15 Um ano após o anúncio da crise americana, o jornal francês Le Monde publicou matéria sugerindo que Lula esteve correto em seu diagnóstico. 
A tese da "nova classe média" conduziu Marcelo Neri a uma rápida ascensão (e queda) política. Na transição do governo Lula para o governo Dilma Rousseff, a partir de 2011, o economista passou a participar de avaliações de programas sociais e de reuniões do Conselho Nacional de Desenvolvimento Econômico e Social (CDES). Em 2012, assumiu a presidência do Ipea e, em março de 2013, com a saída de Moreira Franco para a Secretaria de Aviação Civil (SAC), tornou-se ministro interino da SAE, sendo oficializado no ano seguinte no mesmo cargo, onde deu continuidade à agenda de pesquisas sobre classe média e introduziu novas metodologias, como o índice de satisfação com a vida, mensurado pelo Gallup World Poll. ${ }^{16}$ Nesse mesmo período, Neri foi escolhido como um dos cem brasileiros mais influentes, segundo pesquisa anual realizada pela revista Época. Fabio Giambiagi (2010), economista integrante do BNDES e do Ipea, escreveu:

Marcelo dedica-se ao sacerdócio de "ler" os números. Por isso, ganhou o direito de frequentar diferentes "igrejas" e ter todo tipo de interlocutores. É uma das poucas pessoas capazes de ser chamadas um dia para discutir com o ex-presidente FHC e no dia seguinte tratar do mesmo assunto com o presidente Lula.

\section{A "nova classe média" ganha o mundo}

Tomando como ponto de partida o trabalho seminal de Neri, as principais páginas de jornais do país e do mundo passaram a escrever a crônica da "nova classe média". Em novembro de 2009, a revista The Economist publicou uma reportagem de capa intitulada "Brazil takes off", à luz da imagem do Cristo Redentor decolando. ${ }^{17}$ Imagens que antes clamavam pelo combate à pobreza eram agora substituídas por comportadas famílias sorridentes posando em ambientes domésticos povoados por objetos de consumo; outras procuravam

16 Criado em 2005, ele se baseia em mais de 100 variáveis qualitativas com impacto direto sobre a opinião e a qualidade de vida das pessoas, em mais de 160 países. O indicador tem sido cada vez mais usado por economistas "sociais" em todo o mundo, assim como por pesquisas do Banco Mundial e das Nações Unidas que lidam com desenvolvimento, pobreza e inclusão laboral e social.

17 Quatro anos depois, a mesma revista lançou a imagem da estátua em queda livre, sob o título “Has Brazil blown it?”. As notícias operam, portanto, como termômetros sociais que atestam a circulação internacional da tese da "nova classe média". 
acentuar os contrastes e ambivalências que ainda existiam, à frente de suas (muitas vezes) precárias habitações em zonas periféricas de grandes cidades. Embora não fosse unanimidade, a tese da "nova classe média" expandiu-se no circuito midiático, político e científico.

A partir de uma catalogação dos dez principais jornais brasileiros foi possível documentar a rápida trajetória e evolução da tese da "nova classe média". Foram levantadas 2159 matérias relacionadas ao termo, entre janeiro de 2001 e abril e 2014. Na Figura 3 vemos sua distribuição relativa aos anos. É possível constatar seu aparecimento como "frente discursiva" em 2008 - ano do lançamento da pesquisa de Neri -, seu auge em 2012, e sua progressiva diminuição a partir de então.

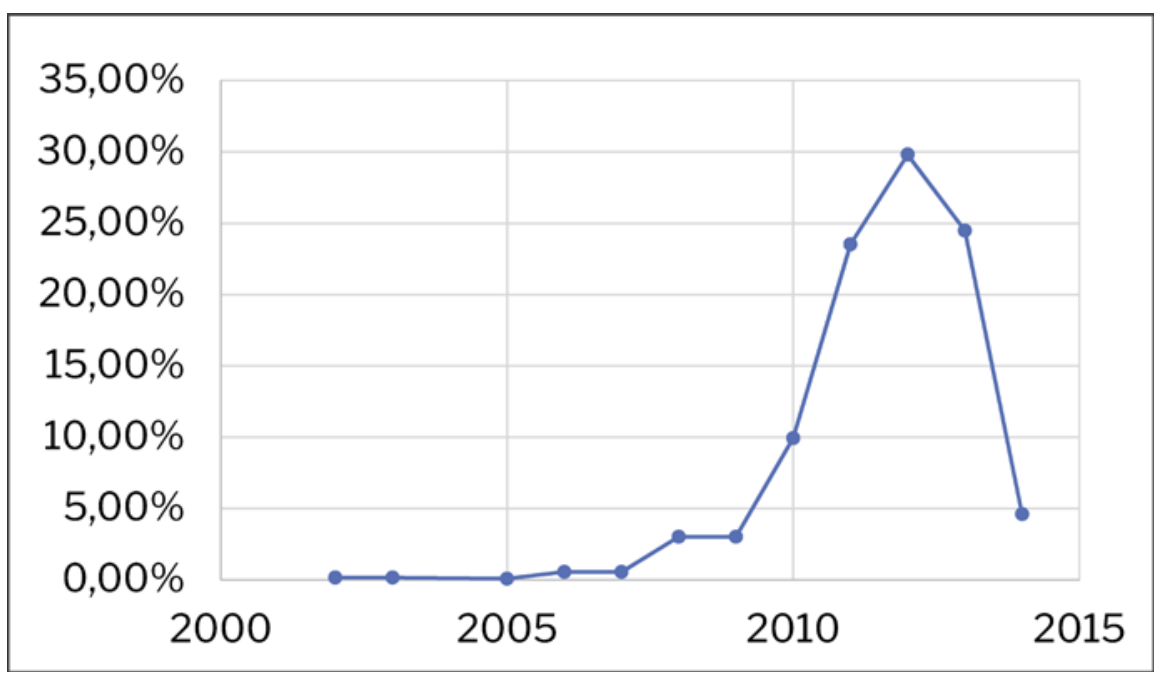

Figura 3. Distribuição de matérias de jornal sobre a "nova classe média".

Em seu conjunto, consideramos essas reportagens evidências empíricas - ou, nos termos de Boltanski e Thévenot (2006), "provas sociais" - da formatação de um debate taxonômico sobre a mobilidade na década de 2000. Elas são vetores que ativamente emolduraram os termos da discussão, forjando um espaço social através do qual equilíbrios de poder foram seguidamente 
negociados. Editoriais como o do The Economist (Brazil..., 2009), ao produzirem leituras hegemônicas sobre a realidade, ao lançarem os termos do debate, ao desenharem diretrizes de política econômica e ao vaticinarem quedas, ajudaram a constituir a temporalidade dessa taxonomia. Assim, essa ciclicidade é também a ciclicidade das vidas públicas dos principais personagens que compõem a tese da "nova classe média": por meio de jornais e entradas televisivas, foram veiculadas as evoluções de seus projetos político-intelectuais, suas alianças difusas e atravessamentos entre Estado, mercado e ciência e, mais importante, as escaladas e derrocadas profissionais que fizeram de sua própria mobilidade subjetiva uma metáfora para a mobilidade da "nova classe média" como projeto para o Brasil.

Como uma fábula que visou narrar uma história de desenvolvimento e sucesso, a "nova classe média" foi performada e agenciada enquanto categoria, modelando uma certa percepção acerca dos rumos do país durante a década de 2000. Assim, a retirada de Neri das posições políticas que tornaram seu argumento visível ocorreu em consonância com a evanescência desse alinhamento. Meses após as eleições presidenciais de 2014 - e de assumir o planejamento da campanha de Dilma Rousseff à reeleição ${ }^{18}$ - Neri pediu exoneração do cargo de ministro da SAE..$^{19}$ Essa sequência de eventos coincidiu, igualmente, com a consolidação da crise econômica - marcada pela queda vertiginosa do PIB, aumento da inflação e do desemprego -, o que deslocou a fundamentação estatística da tese do economista. Ao mesmo tempo, na circulação de posições políticas associadas à leitura dos números públicos brasileiros, o Ipea, então vinculado à SAE, conheceria seu novo presidente: o sociólogo Jessé Souza, um dos críticos mais ácidos do conceito de "nova classe média".

18 Conforme matéria do jornal Valor Econômico de 20 de maio de 2015 (cf. Renda..., 2014).

19 Em entrevista concedida à revista InfoMoney em dezembro de 2015, Neri confessou: "No ano passado houve uma campanha muito dura, com muito calor e pouca luz. Não saí do governo exatamente por causa disso, mas confesso que a campanha não me deixou muita vontade de ficar. No final de novembro, coloquei meu desejo de sair" (Mortari, 2015, p. 21). 


\section{A evanescência da "nova classe média": os caminhos da contestação}

\section{O mal-estar entre os sociólogos}

Com o congelamento e posterior queda dos índices econômicos e de bem-estar que fundamentavam a tese da "nova classe média", Neri sairia de cena e daria lugar ao principal porta-voz de uma crítica sociológica na interpretação dos dilemas contemporâneos do Brasil. Jessé Souza ${ }^{20}$ foi o primeiro sociólogo a assumir a presidência do Ipea. ${ }^{21}$ Nos livros em que buscou contestar a tese da "nova classe média" (Souza, 2009, 2010), Jessé Souza criticou as teorias que associam o "atraso" brasileiro às origens históricas coloniais. ${ }^{22}$ Resultado de pesquisas quali-quantitativas conduzidas em diferentes partes do país, sua obra é dedicada a desenvolver o argumento de que o Brasil teria assistido à emergência de uma "nova classe trabalhadora", visto que faltaria a essa população o principal atributo que caracterizaria a classe média como tal: o acesso privilegiado ao capital cultural que legitima sua participação no mercado e no Estado. Suas análises foram inspiradas em uma linhagem "weberiana" de classe (Weber, 1999), pontuada por marcadores de status, prestígio e distinção, e têm ainda a influência de Bourdieu (1984a, 1984b, 1987, 2001, 2005a, 2005b, 2006), para quem a luta de

20 Com graduação em direito e doutorado em sociologia, Souza foi professor da UnB entre 1992 e 2003, da UFJF entre 2005 e 2014, e atualmente está vinculado à UFF, tendo circulado por instituições como o Iuperj e a USP.

21 Como vemos, o Ipea foi um importante espaço de consagração e teste das ideias sobre mobilidade econômica, constituindo-se como arena privilegiada por onde circularam adeptos e críticos da tese da "nova classe média". Fundado em 1964, o instituto insere-se numa estrutura governamental voltada para o planejamento brasileiro (Barbosa, 2012). Vinculado desde 1967 ao Ministério do Planejamento, consagrou o modelo desenvolvimentista brasileiro baseado no padrão fordista-keynesiano, com o Estado exercendo papel ativo no sistema público de planejamento, ao mesmo tempo em que criava sua própria estrutura e burocracia (Barbosa, 2012). Desde seu nascimento, o Ipea esteve vinculado às preocupações internacionais de planejamento estratégico e policymaking, razão pela qual se conservou como instituição internacionalizada, contando com a colaboração de pesquisadores estrangeiros (D’Araujo; Farias; Hippolito, 2005).

22 Sua indisposição recai sobre a literatura histórico-sociológica brasileira que dá grande ênfase à problemática do "atraso" desenvolvimentista, tomando como parâmetros de comparação os paradigmas estruturais, econômicos e sociais que se desenvolveram nos grandes centros (Botelho; Schwarcz, 2009; Ricupero, 2008; Roiz, 2010). 
classes é, essencialmente, uma luta de classificações taxonômicas e uma luta pelo monopólio da definição legítima do mundo social.

A nomeação de Souza para o Ipea não deixa de ser surpreendente, pois ele havia representado até então uma das principais vozes dissonantes da tese da "nova classe média". Uma mudança de perspectiva tão radical seria esperada no caso de uma mudança no governo, mas Souza foi alçado ao posto por Dilma Rousseff, logo no início do seu segundo mandato. Embora se tivesse convertido num dos críticos mais efusivos do golpe parlamentar que depôs Dilma Rousseff em 2016, a ascensão de Souza parecia enunciar o descarte de uma das políticas econômicas mais bem-sucedidas do segundo governo Lula, calcada no incentivo ao consumo das classes baixas, que tornou o "tsunami" de 2008 uma "marolinha". Para o sociólogo, o desafio estava em superar o modelo de desenvolvimento baseado na popularização do consumo de baixa renda para investir na expansão da estrutura de produtividade e de oferta.

Em entrevistas concedidas logo após sua nomeação, sob o título de "O Brasil não conhece o Brasil, só faz de conta", o sociólogo apresentou uma nova agenda de pesquisas intitulada Radiografia do Brasil moderno: onde estamos e para onde podemos ir, que buscaria "descobrir como capacitar essa classe de trabalhadores que cresceu muito nos últimos anos, para que ela seja capaz de assimilar novas tecnologias e aumentar sua produtividade" (Paula, 2016). Ao sugerir, na mesma entrevista, que $70 \%$ da população era pobre, Souza foi questionado sobre a mudança de nomenclatura no interior do governo, que até então sustentava ter o Brasil mais da metade da população na classe média. "O termo não é o principal; é inegável que houve ascensão" - retrucou o sociólogo; e "este grupo é o foco central da capacitação".

Souza mobilizou sua crítica ainda em redes acadêmicas e científicas, como o seminário temático As Classes Sociais no Brasil Cntemporâneo, nas reuniões anuais da Anpocs. “Aqui eu não quero apenas 'dizer' a crítica”, ele começou. "Eu quero enfrentar o desafio de 'comprová-la' com o meio típico do debate científico por excelência que é a competição entre argumentos". E arrematou, triunfalmente: "Entre nós confunde-se o tempo todo o poder interpretativo dos conceitos com as posições políticas pessoais dos autores que as enunciam com resultados previsivelmente lamentáveis." Souza esbravejou uma crítica aos intelectuais que, tendo uma ideia, "pretendem realizá-la e torná-la prática no Estado" e sugeriu que, ao contrário, "o debate de ideias científicas é a primeira trincheira da luta política e da luta de classes” (Souza, 2013, p. 8). 
Outros sociólogos também criticaram o uso pouco criterioso do conceito de classe (Xavier Sobrinho, 2011), bem como sua apropriação por políticos, economistas, marqueteiros e jornalistas para celebrar a inclusão social, o acesso à cidadania e a abertura de mercados de consumo para os chamados "ex-pobres". Podemos dividir essas abordagens em dois grupos distintos. De um lado, os adeptos do weberianismo problematizaram a formação de estratos intermediários a partir de níveis de ocupação e não exclusivamente através da renda ou posse de bens. Scalon e Salata (2012, p. 391), por exemplo, basearam-se nos trabalhos de John Goldthorpe (2000) e Erik Olin Wright (1986) e tomaram a estrutura de oportunidades e características de classe dos indivíduos para demarcar sua posição na sociedade - o que os conduziria ao compartilhamento de condições de classe semelhantes. Pra eles, portanto, o uso do termo "nova classe média" ter-se-ia mostrado fora de contexto, tanto em relação à relativa constância entre os intervalos estamentais da sociedade quanto em relação à estrutura de ocupações: “Ao invés de falarmos de uma nova classe média poderíamos ponderar, talvez, sobre uma parcela da classe trabalhadora que, em relação a certas características, quase exclusivamente os rendimentos, estaria se aproximando dos setores mais baixos das classes médias" (Scalon; Salata, 2012, p. 403).

Outro estudo, publicado pela Confederação Nacional da Indústria (CNI), sugeriu que os processos de formação de classes médias, enquanto tendência mundial, precisavam ser entendidos na conjunção de processos individuais e estruturais. A mobilidade (entre e dentro de estratos sociais) teria ocorrido em uma estrutura que estava ela mesma em mutação (Souza; Lamounier, 2010). Para os autores, a sustentabilidade dessa "nova classe média" dependia de fatores econômicos (ritmo e composição do crescimento e processos estruturais dele decorrentes), "weberianos" (educação, empreendedorismo, atitudes em relação ao trabalho, etc.) e, finalmente, de recursos políticos (capacidade de articular seus interesses, de pressionar o sistema político e, no limite, de "projetar uma visão da sociedade consentânea com seus objetivos e valores") (Souza; Lamounier, 2010, p. 4). Nesse quadro, argumentou o estudo, a tese da "nova classe média" encontraria dificuldades para se consolidar. De um lado, os processos de ascensão econômica não haviam inibido significativamente os índices de desigualdade, nem tinham sido realizadas reformas estruturais essenciais como a trabalhista e a tributária - o que explicaria, ainda, forte presença de setores informais na economia. De outro, a mobilidade ter-se-ia 
constituído, essencialmente, sobre a ampliação do consumo, e não de novos padrões de organização cultural.

\section{Reviravoltas no interior do PT}

A tese da "nova classe média" que, como temos argumentado, surfou a onda da prosperidade enunciada pela mídia, nacional e internacional, e agências governamentais, também enfrentou resistências diversas, até mesmo de segmentos ideologicamente antagônicos. Não deixa de ser surpreendente que as críticas efetivadas por estudos encomendados pela CNI encontrassem eco em intelectuais de formação marxista, militantes "históricos" do Partido dos Trabalhadores.

Esse era o caso do economista Marcio Pochmann, que publicou dois livros (Pochmann, 2012, 2014) dedicados à contestação do argumento de Neri. A partir de uma análise da estrutura de ocupações da população, ele sugeriu que o crescimento econômico com redução da desigualdade não teria implicado uma mudança de classe. Nas suas palavras:

O grosso da população emergente não se encaixa em critérios sérios e objetivos de classe média. Associam-se, sim, às características gerais das classes populares, que, por elevar o rendimento, ampliam imediatamente o padrão de consumo. Trata-se de um fenômeno comum, uma vez que trabalhador não poupa, e sim gasta tudo que ganha. (Pochmann, 2012, p. 10).

O economista pós-graduado pela Unicamp, e com extensa produção bibliográfica sobre políticas sociais e do trabalho, ${ }^{23}$ foi nomeado em 2007 para a presidência do Ipea, após circular por outros cargos políticos como a Secretaria Municipal do Desenvolvimento, Trabalho e Solidariedade, no governo petista da prefeita Marta Suplicy (2001-2005), em São Paulo. Em 2012, Pochmann, após anunciar sua candidatura à prefeitura de Campinas, foi substituído por

23 Além de seus livros críticos, publicados anos após a tese de Neri, Pochmann publicou, como presidente do Ipea, inúmeras notas e estudos em que reconhece o padrão de mudanças da década de 2000, mas rejeita uma discussão sobre "classe média". Ver, por exemplo, Pobreza e riqueza no Brasil metropolitano (Pochmann, 2008). 
Marcelo Neri na presidência do Ipea - que em pouco tempo acumularia o cargo com o de ministro interino da SAE. A troca institucional ocorreu num momento em que a tese da "nova classe média" atingiu seu pico na esfera pública - incentivada pelo crescimento do PIB e pela subida do Brasil ao posto de sexta maior economia mundial em 2011.

Marcio Pochmann, contudo, não foi o único a tomar parte nessa frente. Intelectuais com destacada atuação pública, entre os quais a filósofa Marilena Chauí, também o fizeram e adquiriram notoriedade por suas críticas estridentes à tese da "nova classe média". Um desses eventos paradigmáticos ocorreu durante uma cerimônia de lançamento do livro 10 anos de governos pós-neoliberais no Brasil: Lula e Dilma, de autoria de Emir Sader, em São Paulo, em maio de 2013. Além de chefes de Estado e autoridades políticas, estiveram presentes intelectuais cuja trajetória era atravessada por filiações ou predileções pelo partido. Partindo de explicações históricas sobre as conquistas sociais e jurídicas das classes trabalhadoras europeias, Chauí argumentou:

Não é pela escolaridade, pela renda, pela profissão, pelos gostos de consumo, que eu determino uma classe social. Isso não define uma classe social no modo de produção capitalista. $\mathrm{O}$ que a define é a maneira pela qual ela se insere nos meios sociais privados da força produtiva. Portanto, critério ABCDE, EFJH, o alfabeto inteiro, não quer dizer coisa nenhuma. [...] A perspectiva de que dispor de um conjunto de bens de consumo em massa, e dispor de um conjunto de direitos sociais significa mudar de classe, não. Significa que a classe conquistou os seus direitos, o seu lugar. ${ }^{24}$

Após uma breve explicação das razões teóricas de sua discordância em relação à tese de uma "nova classe média", Chauí esbravejou:

E por que eu defendo esse ponto de vista? Não é só por razões teóricas e políticas. É porque eu odeio a classe média. A classe média é um atraso de vida. A classe média é a estupidez. É o que tem de reacionário, conservador, ignorante, petulante, arrogante, terrorista. É uma coisa fora do comum a classe média [...].

24 Texto transcrito de fala disponível em: https://www.youtube.com/watch?v=fdDCBC4DwDg (acessado em 30/01/2017). 
A classe média é uma abominação política porque ela é fascista. Ela é uma abominação ética porque ela é violenta. E ela é uma abominação cognitiva porque ela é ignorante. ${ }^{25}$

Em tom de deboche, o ex-presidente Lula, que assistia à fala da filósofa, exclamou: "Agora, depois de tantos anos de luta, que eu cheguei a ser considerado de classe média, essa mulher avacalha com a classe média! Não é possível! [risos]." ${ }^{26} \mathrm{O}$ provocativo desabafo da intelectual gerou uma repercussão interminável na mídia e produziu um extenso conjunto de publicações e reações enfurecidas em diferentes veículos de comunicação pela internet. O que essas críticas evidenciaram é que os discursos sobre o recente processo de mobilidade social nunca foram, estritamente, apenas argumentos, mas produziram e refletiram engajamentos morais de um tipo particular, causando tanto mais estranheza ou repulsa quanto mais evidentemente tivessem sido enunciados por intelectuais, a quem sempre competiu renovar a crença numa separação radical entre o universo das ideias e os contextos sociais da sua produção.

Em geral, para esse grupo, poderíamos dizer que a produção da crítica se baseou em definições marxistas de mobilidade social, que não poderiam ser mais que conjunturais, já que nesse modelo é a sociedade que está em movimento, o que não mudaria a distância relativa das ocupações dos sujeitos em questão. No máximo, portanto, seria possível especular sobre coisas como capital cultural e social na definição dessas posições, em todo caso pouco dinâmicas no tempo e no espaço.

\section{O mercado da "nova classe média"}

A habilidade de Neri em "ler os números" não repercutiu apenas entre policymakers e intelectuais com atuação pública destacada. Apesar das contestações - incluindo-se a crítica especializada, de viés weberiano e marxista, mas também a crítica difusa, mais bem retratada na satírica crônica de Luís Fernando

25 Texto transcrito de fala disponível em: https://www.youtube.com/watch?v=fdDCBC4DwDg (acessado em 30/01/2017).

26 Texto transcrito de fala disponível em: https://www.youtube.com/watch?v=fdDCBC4DwDg (acessado em 30/01/2017). 
Verissimo que abre este artigo -, a tese da "nova classe média" floresceu e gerou frutos. Nesta seção, exploramos outro alinhamento produtivo dessa assemblage da mobilidade: a reinvenção do marketing voltado ao mercado consumidor de baixa renda (Kopper, 2015). Institutos de pesquisa de mercado e experts especializados nesse público consumidor foram gestados e celebraram contratos milionários de consultoria com empresas interessadas em comercializar para o novo público-alvo. Ao mesmo tempo, um boom de notícias e números sobre consumo alastrou-se pela mídia: rendas familiares generosas, acesso a crédito e a bens duráveis, potencial de consumo anual de mais de $\mathrm{R} \$ 1$ trilhão (US\$ 461 bilhões).

"Estudo o tema da evolução de renda há 11 anos e, desde o início, considerei Neri uma referência", disse em 2012 Renato Meirelles, diretor do instituto de pesquisas de mercado Data Popular, referindo-se ao economista e, seguindo o publicitário, principal responsável por dar à "nova classe média" "um rosto humano que as estatísticas escondiam". ${ }^{27} \mathrm{O}$ instituto surgiu em 2001 como ramificação da Popular Comunicação, uma agência de comunicação e marketing que já encabeçava um esforço de voltar suas estratégias de mercado para as "classes populares". ${ }^{28}$ Meirelles ascendeu rapidamente às posições de comando da empresa até tornar-se reconhecido publicamente como sócio-diretor do instituto (para uma discussão detalhada, ver capítulo 2 de Kopper, 2016).

Ao longo desse processo, a agência utilizou uma profusão de termos para referir-se aos alvos da mobilidade econômica: "ex-pobres", "classes populares", "base da pirâmide", "classe C" e, finalmente, "nova classe média". A transição refletia as influências intelectuais de Meirelles e de seu time interdisciplinar de experts, composto de sociólogos, antropólogos, economistas, demógrafos.

27 Em entrevista concedida à revista Época por ocasião da seleção das cem pessoas mais influentes do ano (Meirelles, 2012).

28 O Data Popular foi o primeiro instituto de pesquisas de mercado focado especificamente na "base da pirâmide" brasileira e constituiu, por essa razão, um foco privilegiado da pesquisa etnográfica que originou este artigo. A partir dele, foram fundados outros dois institutos com expertise nesse segmento: A Ponte Estratégia e Plano CDE. Além do acompanhamento de palestras e atividades promovidas pela instituição, foram conduzidas entrevistas com seu presidente-fundador, os coordenadores do setor de pesquisas quantitativas e qualitativas, e ex-funcionários. Esta incluiu a realização de entrevistas em profundidade com profissionais na sede do instituto, com ex-funcionários do instituto, e a análise documental e midiática de materiais, notícias e relatórios produzidos pelo instituto. 
A profusão terminológica expôs, igualmente, os caminhos taxonômicos dessa assemblage, e os modos pelos quais as ideias circulavam e passavam de um registro ao outro: da ciência ao governo, do governo ao mercado e, novamente, de volta à ciência. Ao aterrissar, finalmente, na tese da "nova classe média", a agência de publicidade admitia que havia algo novo em termos de classe - passando a oferecer serviços especializados em perscrutar o seu gosto - sem descartar os achados advindos da antropologia urbana, que focavam nos modos de vida dessa população e apontavam para os limites de teorizações sociológicas baseadas na distinção e na perspectiva da trickle down (Bourdieu, 1984a).

A criação de um instituto de pesquisas com as peculiaridades do Data Popular respondia, por conseguinte, às demandas de mercado, ávido por ampliar seu conhecimento a respeito do gosto do público não elitizado. "Existia um grande preconceito no mercado em ter uma agência de propaganda pra classe C e D", confessou Meirelles em entrevista concedida aos autores em 2014. "A propaganda aprendeu a fórceps [sobre] essa classe média. Eles têm uma dificuldade de entender que o Leão de Cannes, que é o maior prêmio da propaganda mundial, não vale nada para quem mata um leão por dia para sobreviver". Sua crítica - uma versão nacional do argumento de Prahalad (2005) sobre a riqueza na "base da pirâmide" 29 -, era de que "a propaganda cresce com a teoria do aspiracional, de que todos querem ser melhores, e esculhamba as pessoas pra que elas se sintam mal e achem que a compra do produto é a única forma delas se sentirem bem". Para a "nova classe média", entretanto, "isso não funciona. Ela tá com a autoestima elevada, quer ser reconhecida, e ela acha o rico o babaca, o maior perdulário."

Em pouco tempo, por meio de generosas matérias midiáticas e contratos de alta monta com clientes interessados em suas pesquisas e metodologias, ${ }^{30}$ seu nome transformou-se numa espécie de selo certificador dos saberes

29 O argumento de Prahalad (2005) sugeria que era possível erradicar a pobreza através da invenção de novos modelos massificados de mercado. Observando a sociedade como uma pirâmide, ele argumentou, sua base figura como o grupo mais pobre, mas também como o mais volumoso, constituindo um potencial de 4 bilhões de consumidores.

30 Em 2015, os clientes incluíam, por exemplo, bancos (como Itaú, IBI, Bradesco, Citibank, Lemon Bank, Unibanco, Mastercard), a Bovespa, Casas Bahia, Magazine Luiza, Walmart, Marabraz, Coca-Cola, editoras (Abril, Alto Astral), Grupo Algar, Grupo Pão-de-Açúcar, Grupo Positivo, Grupo Sílvio Santos, ministérios governamentais (do Trabalho, do Turismo), partidos políticos (PCdoB), e por aí afora. 
produzidos sobre a "nova classe média". A partir de 2013, ele passaria menos tempo na agência, concentrando-se na concessão de entrevistas e palestras decorrentes da visibilidade adquirida. No processo, a conversão da agência de marketing em um instituto de pesquisas lhe permitiu ancorar os resultados produzidos em uma linguagem científica, manipulada por uma equipe técnica e multidisciplinar capaz de engendrar um "produto diferenciado". Em nossa conversa, em 2014, Meirelles explicou:

A equipe do Data Popular aqui é muito multidisciplinar. Então eu sou publicitário de formação; a Marlise, que é meu braço direito aqui, tem mestrado em Ciências Sociais na USP; Adriane, que é gerente de pesquisa qualitativa, tem doutorado no Museu Nacional [...] Eu tenho o Márcio que é economista, mais estatístico, então a gente consegue ter um time com uma visão de mundo muito plural, e produzir relatórios que efetivamente passam por todos esses crivos.

A capacidade persuasiva de Meirelles residia no uso de "casos" e números para contar a história dos consumidores de classe média - de tal modo que a criação do personagem publicitário foi coetânea à criação de personagens-consumidores que, ao descobrirem o mercado como espaço de satisfação de seus desejos, narravam crônicas de mobilidade econômica, superação da pobreza e redefinição de suas identidades. As falas do publicitário estavam povoadas por tais encontros fortuitos, e seguiam o roteiro de uma descoberta antropológica do Outro. Tivemos a oportunidade de registrar uma de suas performances em 2014, ocorrida na PUCRS, diante de uma audiência de estudantes de jornalismo. ${ }^{31}$ O relato abaixo, extraído deste mesmo evento, dá uma ideia de suas estratégias de persuasão:

Eu conheço a Candeia, já fui na casa da Candeia, nunca tive um caso com a Candeia, juro pra vocês. Mas a Candeia já viajou de avião a essa altura do campeonato mais de seis vezes. Candeia tem cinco cartões de crédito. A Candeia tá fazendo

31 Em geral, as palestras de Meirelles eram destinadas a empresas privadas interessadas em treinamento de pessoal, mas naquela noite o evento fora promovido por uma deputada federal esquerdista com grande circulação entre jovens intelectualizados do Rio Grande do Sul, interessados em "atualizar" seus conhecimentos sobre a "realidade brasileira", nas palavras da política. 
terapia porque tá de saco cheio do marido. E se eu falasse pra vocês, alguém que tem cartão de crédito, viaja de avião, faz terapia, pode ser assinante do seu jornal, pode comprar o seu produto? Claro que pode! $\mathrm{E}$ quantas vezes se faz comunicação pensando na Candeia? E só de Candeias [empregadas domésticas] eu tenho sete milhões no Brasil! Agora, a Candeia tem alguma cara de quem quer ficar parecida com a patroa? Nenhuma! A patroa é perdulária, joga dinheiro fora. Não entende por que na hora do almoço só come um franguinho com salada podendo comer um prato cheio. A classe $\mathrm{C}$ definitivamente não aspira mais ser como a classe $\mathrm{A}$. Só que a classe $\mathrm{C}$ movimenta por ano 1,17 trilhão de reais! É tanto dinheiro que se a classe média fosse um país, ela seria o $12^{\circ}$ maior país do mundo em população, o $18^{\circ}$ maior país do mundo em consumo, ela estaria no G20 do consumo mundial. Então nós não tamos mais falando de um nicho de mercado, ou de um nicho de cidadãos, ou de um nicho de consumidores. Nós estamos falando do verdadeiro mercado brasileiro.

Como vemos, a invenção desses consumidores ativistas - quer dizer, ávidos por serem capturados pelas histórias do publicitário e pelas campanhas de marketing - esteve ajustada ao uso de poderosos métodos qualitativos de pesquisa que implicaram sua participação ativa no design de novos produtos que satisfizessem suas "necessidades". E, óbvio, na invenção de personagens como Candeia, capazes de personificar não apenas um novo consumidor - consumidora, nesse caso - mas também um cidadão, com aspirações próprias. Assim, consultores e tecnologias metodológicas compuseram redes sociotécnicas capazes, simultaneamente, de engajar-se com e falar em nome de consumidores da "nova classe média".

Ao reapropriar falas e opiniões da "nova classe média" em discursos controlados, Meirelles edificou-se a si próprio como personagem central de um processo de experimentação criativa com a diferença e com o imaginário de seus interlocutores de pesquisa. Buscando canais de comunicação com públicos geralmente elitizados, suas falas invertiam posições sociais e deslocavam valores e práticas culturais de contexto, gerando risadas no público.

Nessas palestras, a expertise do publicitário como consultor era construída ao longo de diferentes etapas. Primeiro, era preciso estabelecer a "classe C" como um universo específico, distante do entendimento de seus pares; essa dissidência era formatada como uma diferença de percepções de classe e performada 
com recurso a vídeos produzidos pelo instituto onde eram confrontadas opiniões de patroas e empregadas quanto à rotina de trabalho destas últimas. Para explicar essas diferenças, eram invocados os analistas do Data Popular - figuras necessárias nessa cadeia explicativa da alteridade - para argumentar que "consumir significa esquecer do passado de pobreza". A experiência de compra era vista então como um momento de empoderamento e inclusão social.

Em seguida, Meirelles apresentava-se como personagem-aprendiz em interações com pessoas da "classe $C$ ", através de casos paradigmáticos extraídos de pesquisas qualitativas realizadas pelo instituto. Usando vinhetas desses encontros, o publicitário transportava sua audiência para complexos habitacionais na periferia de São Paulo, onde convivera com uma família por uma semana e só fora assimilado após aceitar dois pratos de comida à mesa. Noutro caso, morando no morro Dona Marta, Rio de Janeiro, Meirelles contava como fora instruído por uma mulher negra sobre a lógica de suas decisões na compra de uma lavadora de roupas:

- Finalmente eu comprei a primeira máquina de lavar roupas da minha família.

- Como é que a senhora pagou?

- Como pobre paga, eu fiz um carnê.

- Por acaso você fez as contas pra saber quanto de juros você tá pagando?

- Claro que fiz, eu não sou burra.

Pah, pah, idiota, né, de novo [risos da plateia].

- E por que a senhora não guardou o dinheiro pra pagar à vista e fazer uma economia?

Ela olhou pra minha cara e falou:

- Renato, com essa carinha de rico, você nunca lavou roupa no tanque na sua vida, né? Porque senão você iria entender por que eu não passo todo o dia estragando o esmalte lavando roupa quando eu posso ter a minha máquina de lavar. Eu quero ter a minha máquina de lavar agora!

E não nos cabe com a lógica da elite, da planilha do Excel, da racionalidade da classe A e B, decidir o que é melhor pra Dona Maria, se é estragar o esmalte ou se é pagar parcelado.

Esbofeteado pelas "verdades" apreendidas "em campo", Meirelles exagerava no uso de expressões e interjeições para desenhar uma caricatura desse consumidor 
e radicalizar sua predisposição em aprender com o Outro. Colocando-se momentaneamente na posição de escuta, do subalterno - uma estratégia amplamente utilizada pela antropologia -, do observador das diferenças culturais, o publicitário operava deslocamentos de contexto e se valia de figuras de linguagem para cristalizar a distância e o seu deslocamento engajado para entendê-la. Ao retornar, em seguida, para narrar essa experiência, o personagem de Meirelles em suas histórias tornava-se a caricatura de seu próprio interlocutor.

Essas vinhetas eram, contudo, mais que artifícios de legitimidade para afirmar a autoridade de Meirelles como expert na "nova classe média". Em sua viagem cultural, uma importante revelação era feita: o sujeito encontrado e imaginado por Meirelles descobria-se como consumidor dotado de desejos e, mais importante, de um conhecimento de si e dos meios para satisfazê-lo. A ideia permitia ao publicitário falar das populações-alvo no interior da "nova classe média": os negros, os jovens, as mulheres. Longe de serem simples categorias econômicas, elas refletiam estratos economicamente governáveis e tornados evidentes por meio das pesquisas de mercado (Rose, 2007). A exposição dessas populações como categorias de consumidores implicava ainda a garantia de que dispunham da liberdade de escolha no espaço do mercado - uma liberdade que podia ser escrutinada, explorada e refinada pelo marketing. Era nessa economia política e científica que a pesquisa de mercado tornava visíveis os cidadãos-consumidores da "nova classe média".

\section{Considerações finais: o(s) destinos(s) da "nova classe média"}

Ao longo de praticamente uma década - entre 2001 e 2012 - economistas, sociólogos, planejadores públicos, antropólogos, políticos e jornalistas estiveram empenhados em registrar os efeitos redistributivos do aumento real do salário mínimo, da estabilidade econômica, de políticas sociais, do bônus demográfico, sobre as vidas de brasileiros, e o fizeram apostando na emergência de um novo estrato social: uma "nova classe média". Ao apontar para os alinhamentos produzidos em diferentes esferas, mostramos como essa concertação coproduziu-se como uma linguagem moral sob a qual foram contadas histórias de esforço pessoal, superação da pobreza, de reconstrução nacional e desenvolvimento econômico. 
Neste artigo, portanto, procuramos deslindar a história social de um conceito em torno do qual se formou uma assemblage de múltiplas escalas que definiu a mobilidade econômica da década de 2000. Nesse esforço de arqueologia categorial, identificamos e exploramos os alinhamentos políticos, econômicos e científicos que performaram a aparição meteórica e posterior evanescência da "nova classe média" como categoria de enunciação da mobilidade. Costurados a partir de personagens e arenas cruciais ao exercício desse embate, os alinhamentos performaram diversas realidades e agenciaram discussões no espectro da economia, da política, da sociologia e do marketing.

Ao enfatizarmos as trajetórias dos personagens dessa mobilidade, que tornaram as teorias vetores de conhecimento e poder, procuramos compreender a materialidade e porosidade dessa assemblage (Rabinow, 2005), e os caminhos que levaram a alinhamentos sociotécnicos que deram sustentação à tese da existência de uma "nova classe média". Acompanhando alguns de seus desdobramentos para a formatação de políticas públicas e aberturas de mercado, evidenciamos a circulação dessas ideias e personagens, bem como seus atravessamentos entre ciência e política. Convertida em linguagem de governo por meio de políticos e jornalistas, a gramática da "nova classe média" buscou reconfigurar os alvos de intervenção do Estado brasileiro em nome de um "novo social" (Rose, 2007). Trazendo para o diálogo a crítica sociológica, apontamos para as moralidades, contradições e limites entre Estado e mercado, produção e consumo, que subjazem a esse dispositivo de classificação que buscou recolocar o país na rota de uma geopolítica internacional.

Sob muitos aspectos, a pedra de toque do debate que se estabeleceu em torno da emergência dessa "nova classe média" esteve ancorada sobre a possibilidade de verificar-se sua existência empírica. Poderiam as transformações apontadas pelas estatísticas sociais ser interpretadas no registro da formação de uma "classe média"? Ou, ao contrário, faltariam evidências sociológicas que sustentassem essa posição? Para além dos jogos políticos de justificação e falseamento que pontuaram essa tensão, procuramos assinalar aqui os múltiplos efeitos taxonômicos desse novo sistema de classificação. Como demonstramos por meio da circulação da categoria em circuitos estatísticos e econômicos, sua penetração no governo federal, as formas de sua contestação e sua apropriação pelo marketing, o que estava em jogo eram lutas simbólicas que 
se materializaram, antes de tudo, em disputas sobre o monopólio legítimo de imprimir um sistema de legibilidade hegemônico da realidade brasileira.

De um ponto de vista antropológico, pois, conceitos são reais na medida em que constituem categorias de apreensão da realidade que são agenciadas para performar aquilo que pretendem tornar inteligível (Boltanski, 1987; Muniesa; Callon, 2007). Vista desse ângulo, a mobilidade econômica se mostrou em múltiplas faces. Da estatística microeconométrica à crítica sociológica - não importa qual o sistema de mensuração - as iniciativas de governo e de mercado aqui captadas sob o signo da "nova classe média" produziram uma nova categoria de pessoas que deslocou os eixos da discussão sobre a sociedade brasileira. Esses debates estruturaram novos campos de ação política e econômica, suspendendo concepções arraigadas e autoevidentes de percepção de classe, em um país ainda altamente marcado por desigualdades de renda e de acesso a políticas públicas.

Com a abertura de novos postos de trabalho, o aumento da renda nominal do salário mínimo, a expansão do acesso ao crédito, a extensão do escopo de políticas sociais, um novo contingente de brasileiros tomou forma, reestruturando expectativas em torno da produção e do consumo, dos papéis do Estado e do mercado, e deixando em aberto seus próprios futuros e a sustentabilidade de seus projetos. Embora com consequências para toda a sociedade - e muitas destas de caráter moral, já que dizem respeito a percepções e práticas de classe até então inacessíveis às demais - certos setores foram nitidamente mais impactados que outros. Do ponto de vista demográfico, mulheres, negros e jovens foram apontados como os protagonistas dessa "nova classe média". Setorialmente, ainda, o país produziu políticas que afetaram diretamente outros segmentos da população, como o Programa Bolsa Família, o Programa Minha Casa Minha Vida, as políticas de expansão de universidades federais e de financiamento estudantil que permitiram maior acesso de jovens de periferia às universidades públicas e privadas, e por aí afora.

Em seu conjunto, essas iniciativas, inicialmente coligidas sob a alcunha da "nova classe média", não desapareceram com a efemeridade de um conceito. Ao contrário: elas abriram espaços imaginativos e campos de cálculo subjetivo em torno de questões e conjuntos de tomadas de decisões sui generis. A ampliação do crédito e da renda, por exemplo, levará, em longo prazo, à autonomia financeira ou conduzirá ao endividamento? $\mathrm{O}$ aumento dos anos de estudo graças à 
expansão do ensino universitário conduzirá a empregos e estilos de vida tipicamente tidos como de classe média, ou produzirá um contingente de trabalhadores desempregados com diploma?

Embora sem respostas para essas questões, este artigo enveredou por uma arqueologia da "nova classe média" e apontou pistas acerca dos desdobramentos da mobilidade econômica da década de 2000. Mostrou, ainda, como essa assemblage se articulou em torno de alinhamentos ou frentes discursivas delineados por economistas, sociólogos, filósofos e outros intelectuais na sua problematização. Em seu conjunto, essas polêmicas revelaram uma novidade desconcertante: como foi possível lidar com a mobilidade ascendente num país cuja intelectualidade foi historicamente mobilizada, salvo exceções, para pensar a estagnação ou a mobilidade descendente? Por essa razão, o período que correspondeu à "vida ativa" do conceito de "nova classe média" constituiu um singular momento da história do Brasil. Sem desacreditar das estatísticas recentes, que sugerem o esgotamento das razões que levaram a mobilidade ascendente, o período aqui analisado produziu uma extraordinária quantidade de textos e argumentos que extrapolaram a discussão sobre a conjuntura econômica. No fundo, sempre estiveram em jogo questões de economia moral, de como seria pensado um país se este viesse a confirmar uma breve tendência - quiçá um lampejo no fim do túnel - de vir a ser diferente do que sempre foi: uma pirâmide.

\section{Referências}

BACHA, E. O rei da Belíndia, o economista visitante e o produto interno bruto. Opinião, Rio de Janeiro, 19 ago. 1974, p. 14-15.

BARBOSA, W. IPEA (Instituto de Pesquisa Econômica Aplicada): planejamento e reprodução do capital (1964 a 2004). 2012. Tese (Doutorado em História)-Faculdade de História, Universidade Federal de Goiás, Goiânia, 2012.

BECKERT, J. Imagined futures: fictional expectations and capitalist dynamics. Harvard: Harvard University Press, 2013.

BOLTANSKI, L. The making of a class: cadres in French society. Cambridge: Cambridge University Press, 1987. 
BOLTANSKI, L.; THÉVENOT, L. On justification: economies of worth. Princeton: Princeton University Press, 2006.

BOTELHO, A.; SCHWARCZ, L. M. (Org.). Um enigma chamado Brasil: 29 intérpretes e um país. São Paulo: Companhia das Letras, 2009.

BOURDIEU, P. Distinction: a social critique of the judgment of taste. Cambridge: Harvard University Press, 1984a.

BOURDIEU, P. Social space and the genesis of groups. Theory and Society, Dordrecht, v. 14, n. 1, p. 723-744, 1984b.

BOURDIEU, P. What makes a social class? On the theoretical and practical existence of groups. Berkeley Journal of Sociology, Berkeley, v. 32, n. 1, p. 1-18, 1987.

BOURDIEU, P. Las estructuras sociales de la economía. Buenos Aires: Manantial, 2001. BOURDIEU, P. Condição de classe e posição de classe. In: BOURDIEU, P. A economia das trocas simbólicas. São Paulo: Perspectiva, 2005a. p. 3-26.

BOURDIEU, P. Principles of an economic anthropology. In: SMELSER, N.; SWEDBERG, R. (Ed.). The handbook of economic sociology. Princeton: Princeton University Press, 2005b. p. 75-89.

BOURDIEU, P. Argelia 60: estructuras económicas y estructuras temporales. Buenos Aires: Siglo XXI, 2006.

BRAZIL takes off. The Economist, 12 nov. 2009. Disponível em: <http://www.economist.com/node/14845197>. Acesso em: 30 jan. 2017.

CALLON, M. Qu'est-ce qu'un agencement marchand?. In: CALLON, M. et al. Sociologie des agencements marchands. Paris: Presses de Mines, 2013. p. 325-440.

CARRARO, A.; FONSECA, P. O desenvolvimento econômico no primeiro governo de Vargas (1930-1945). 2003. Trabalho apresentado. V Congresso Brasileiro de História Econômica/6a Conferência Internacional de História de Empresas, Caxambu, 2003. Disponível em: <http://www.abphe.org.br/arquivos/2003_andre_carraro_pedro_ cezar_dutra_fonseca_o-desenvolvimento-economico-no-primeiro-governo-de-vargas-1930_1945.pdf>. Acesso em: 30 jan. 2017.

COLLIER, S.; ONG, A. Global assemblages, anthropological problems. In: ONG, A.; COLLIER, S. (Ed.). Global assemblages: technology, politics, and ethics as anthropological problems. Oxford: Blackwell Publishing, 2005. p. 3-21.

D'ARAUJO, M. C.; FARIAS, I. C.; HIPPOLITO, L. (Org.). IPEA - 40 anos: apontando caminhos: depoimentos ao CPDOC. Rio de Janeiro: FGV, 2005. 
EGER, T.; DAMO, A. S. Money and morality in the Bolsa Família. Vibrant: Virtual Brazilian Anthropology, Brasília, v. 11, n. 1, p. 250-284, Jan./June 2014.

FAORO, R. Os donos do poder: formação do patronato político brasileiro. São Paulo: Globo, 2008.

FERREIRA, F. et al. Economic mobility and the rise of the Latin American middle class. Washington D.C.: The World Bank, 2013.

FOUCAULT, M. Microfisica do poder. Rio de Janeiro: Graal, 1995.

FRANZONI, J.; SÁNCHEZ-ANCOCHEA, D. Good jobs and social services: how Costa Rica achieved the elusive double incorporation. Geneva: United Nations Research Institute for Social Development, 2013.

FREYRE, G. Casa-grande e senzala: formação da família brasileira sob o regime da economia patriarcal. 51. ed. São Paulo: Global, 2006.

FURTADO, C. Formação econômica do Brasil. São Paulo: Companhia das Letras, 2007.

GIAMBIAGI, F. Marcelo Neri: o acadêmico do combate à pobreza. Época, São Paulo, n. esp., p. 96, 13 dez. 2010. Disponível em: <http://www.cps.fgv.br/ibrecps/clippings/ mc2684.pdf>. Acesso em: 12 jun. 2015.

GOLDTHORPE, J. H. Social class and the differentiation of employment contracts. In: GOLDTHORPE, J. H. On sociology: numbers, narratives, and the integration of research and theory. Oxford: Oxford University Press, 2000. p. 206-229.

HOLANDA, S. B. Raízes do Brasil. 26. ed. São Paulo: Companhia das Letras, 2006.

INSTITUTO BRASILEIRO DE GEOGRAFIA E ESTATÍSTICA. Para compreender a PNAD: um texto simplificado. Rio de Janeiro, 1991.

KOPPER, M. Designing Brazil's new middle class: economic science and welfare policies in the making of a social category. Urbanities, v. 5, n. 2, p. 20-31, 2015.

KOPPER, M. Arquiteturas da esperança: uma etnografia da mobilidade econômica no Brasil contemporâneo. 2016. Tese (Doutorado em Antropologia Social)-Instituto de Filosofia e Ciências Humanas, Universidade Federal do Rio Grande do Sul, Porto Alegre, 2016.

LANGONI, C. G. Distribuição da renda e desenvolvimento econômico do Brasil. Rio de Janeiro: Expressão e Cultura, 1973.

LOUREIRO, M. R.; LIMA, G. T. A internacionalização da ciência econômica no Brasil. Revista de Economia Política, São Paulo, v. 14, n. 3, p. 31-50, 1994.

MEDEIROS, M. As teorias da estratificação da sociedade e o estudo dos ricos. Brasília: IPEA, 2003. (Texto para Discussão n. 998). 
MEIRELLES, R. Marcelo Neri. Época, Rio de Janeiro, n. 761, 17 dez. 2012.

MORTARI, M. O avanço de uma década em xeque. InfoMoney, São Paulo, p. 18-21, nov./dez. 2015. Disponível em: <http://www.compaso.com.br/clipping/rc112.pdf>. Acesso em: 28 jan. 2016.

MÜLLER, L. H. A. Políticas de inclusão e de educação financeira. 2013. Trabalho apresentado. $37^{\circ}$ Encontro Anual da Anpocs, 2013, Águas de Lindóia. Disponível em: <http://www.anpocs.com/index.php/papers-37-encontro/st/st09/8441-financas-significados-e-valores-analise-de-categorias-e-nocoes-que-orientam-as-politicas-de-educacao-financeira/file>. Acesso em: 30 jan. 2017.

MUNIESA, F.; CALLON, M. Economic experiments and the construction of markets. In: MACKENZIE, D.; MUNIESA, F.; SIU, L. (Ed.). Do economists make markets?: on the performativity of economics. Princeton: Princeton University Press, 2007. p. 163-189.

NEIBURG, F. As moedas doentes, os números públicos e a antropologia do dinheiro. Mana, Rio de Janeiro, v. 13, n. 1, p. 119-151, 2007.

NERI, M. A nova classe média: o lado brilhante dos pobres. Rio de Janeiro: CPS/FGV, 2008.

NERI, M. A nova classe média: o lado brilhante da base da pirâmide. São Paulo: Saraiva, 2011.

OLIVEN, R. G. Violência e cultura no Brasil. Petrópolis: Vozes, 1989.

OLIVEN, R. G. Cultura brasileira e identidade nacional (o eterno retorno). In: MICELI, S. (Org.). O que ler na ciência social brasileira (1970-2002). São Paulo: Sumaré: Anpocs; Brasília: Capes, 2002. p. 15-44.

ORTIZ, R. Cultura brasileira e identidade nacional. São Paulo: Brasiliense, 1985.

OSORIO, R. G. et al. Perfil da pobreza no Brasil e sua evolução no período 2004-2009. Brasília: IPEA, 2011. (Texto para Discussão n. 1647).

PAES DE BARROS, R.; FOGUEL, M.; ULYSSEA, G. (Org.). Desigualdade de renda no Brasil: uma análise da queda recente. Brasília: IPEA, 2007. $2 \mathrm{v}$.

PAES DE BARROS, R.; HENRIQUES, R.; MENDONÇA, R. A estabilidade inaceitável: desigualdade e pobreza no Brasil. Rio de Janeiro: IPEA, 2000. (Texto para Discussão n. 800).

PAULA, N. de. 'O Brasil não conhece o Brasil, só faz de conta', diz presidente do Ipea. O Globo, Rio de Janeiro, 27 abr. 2016. Disponível em: <http://oglobo.globo. com/economia/o-brasil-nao-conhece-brasil-so-faz-de-conta-diz-presidente-do-ipea-15983568>. Acesso em: 28 abr. 2016. 
POCHMANN, M. Pobreza e riqueza no Brasil metropolitano. Brasília: IPEA, 2008. (Comunicado da Presidência n. 7).

POCHMANN, M. Nova classe média?: o trabalho na base da pirâmide social brasileira. São Paulo: Boitempo, 2012.

POCHMANN, M. O mito da grande classe média: capitalismo e estrutura social. São Paulo: Boitempo, 2014.

PRADO JR., C. História e desenvolvimento: a contribuição da historiografia para a teoria e prática do desenvolvimento brasileiro. São Paulo: Brasiliense, 1999.

PRADO JR., C. Evolução política do Brasil e outros estudos. São Paulo: Companhia das Letras, 2012a.

PRADO JR., C. História econômica do Brasil. São Paulo: Brasiliense, 2012b.

PRAHALAD, C. K. The fortune at the bottom of the pyramid: eradicating poverty through profits. New Jersey: Prentice Hall, 2005.

QUADROS, W. J. A nova classe média brasileira: 1950-80. 1985. Dissertação (Mestrado em Economia)-Instituto de Economia, Universidade Estadual de Campinas, Campinas, 1985.

QUADROS, W. J. O “Milagre Brasileiro” e a expansão da nova classe média. 1991. Tese (Doutorado em Economia)-Instituto de Economia, Universidade Estadual de Campinas, Campinas, 1991.

RABINOW, P. Midst anthropoology's problems. In: ONG, A.; COLLIER, S. (Ed.). Global assemblages: technology, politics, and ethics as anthropological problems. Oxford: Blackwell Publishing, 2005. p. 40-54.

RAVALLION, M. The Developing World's bulging (but vulnerable) middle class. Washington D.C.: The World Bank, 2009. (Policy Research Working Paper 4816).

RENDA dos mais pobres teve maior avanço com Dilma do que sob Lula, diz Neri. IHU, 20 maio 2014. Disponível em: <http://www.ihu.unisinos.br/noticias/531483renda-dos-mais-pobres-teve-maior-avanco-com-dilma-do-que-sob-lula-diz-neri>. Acesso em: 24 jan. 2016.

RICUPERO, B. (Org.). Sete lições sobre as interpretações do Brasil. São Paulo: Alameda, 2008.

ROCHA, S. Pobreza e desigualdade no Brasil: o esgotamento dos efeitos distributivos do Plano Real. Rio de Janeiro: IPEA, 2000. (Texto para Discussão n. 721). 
ROIZ, D. S. Uma história do pensamento político e social brasileiro: entre o "estado patrimonialista" e a "ação das massas". Sociedade e Cultura, Goiânia, v. 13, n. 2, p. 299302, 2010.

ROSE, N. La muerte de lo social? Re-configuración del territorio de gobierno. Revista Argentina de Sociología, Buenos Aires, v. 5, n. 8, p. 111-150, 2007.

SALATA, A. Notas sobre a tese da nova classe média brasileira. Rio de Janeiro: Observatório das Metrópoles, 2013.

SALATA, A. Quem é classe média no Brasil?: um estudo sobre identidades de classe. 2014. Tese (Doutorado em Ciências Sociais)-Instituto de Filosofia e Ciências Sociais, Universidade Federal do Rio de Janeiro, Rio de Janeiro, 2014.

SCALON, C.; SALATA, A. Uma nova classe média no Brasil da última década? O debate a partir da perspectiva sociológica. Sociedade e Estado, Brasília, v. 27, n. 2, p. 387-407, 2012.

SILVA E SILVA, M. O. O Bolsa Família: problematizando questões centrais na política de transferência de renda no Brasil. Ciência e Saúde Coletiva, Rio de Janeiro, v. 12, n. 6, p. 1429-1439, 2007.

SILVEIRA, H.; ABREU, L.; LOSSO, T. Estado e desenvolvimento: política e relações internacionais no Brasil contemporâneo. Porto Alegre: Asterisco, 2010.

SOARES, S. O ritmo de queda na desigualdade no brasil é adequado?: evidências do contexto histórico internacional. Brasília: IPEA, 2008. (Texto para Discussão n. 1339).

SOUZA, A.; LAMOUNIER, B. A classe média brasileira: ambições, valores e projetos de sociedade. Rio de Janeiro: Elsevier; Brasília: CNI, 2010.

SOUZA, J. Gilberto Freyre e a singularidade da cultura brasileira. Tempo Social, São Paulo, v. 12, n. 1, p. 69-100, 2000.

SOUZA, J. A ralé brasileira: quem é e como vive. Belo Horizonte: Editora UFMG, 2009. SOUZA, J. Os batalhadores brasileiros: nova classe média ou nova classe trabalhadora?. Belo Horizonte: Editora UFMG, 2010.

SOUZA, J. O economicismo e a invisibilidade das classes. 2013. Trabalho apresentado. $37^{\circ}$ Encontro Anual da Anpocs, 2013, Águas de Lindóia. Disponível em: <http://www. anpocs.com/index.php/papers-37-encontro/st/st33/8631-as-classes-populares-para-alem-do-economicismo/file>. Acesso em: 30 jan. 2017.

SPRANDEL, M. A. A pobreza no paraíso tropical: interpretações e discursos sobre o Brasil. Rio de Janeiro: Relume Dumará: Núcleo de Antropologia da Política/UFRJ, 2004. 
TSING, A. L. Friction: an ethnography of global connection. Princeton: Princeton University Press, 2005.

VERISSIMO, L. F. Buuu. Estadão, São Paulo, 29 abr. 2011. Disponível em: <http://cultura.estadao.com.br/noticias/geral,buuu-imp-,711779>. Acesso em: 30 jan. 2017.

WEBER, M. Estamentos e classes. In: WEBER, M. Economia e sociedade: vol. 1. Brasília: Editora UnB; São Paulo: Imprensa Oficial, 1999. p. 199-206.

WRIGHT, E. O. What is middle about the middle class?. In: ROEMER, J. (Ed.). Analytical Marxism. Cambridge: Cambridge University Press, 1986. p. 3-25.

XAVIER SOBRINHO, G. "Classe C" e sua alardeada ascensão: nova? Classe? Média?. Indicadores Econômicos FEE, Porto Alegre, v. 38, n. 4, p. 67-80, 2011.

Recebido: 31/01/2017 Aceito: 08/08/2017 | Received: 1/31/2017 Accepted: 8/8/2017 